
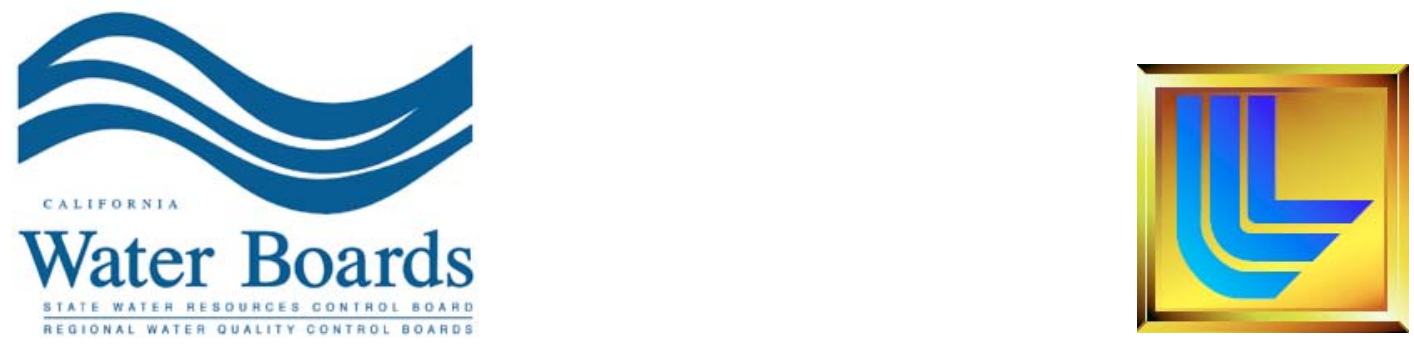

Prepared in cooperation with the

CALIFORNIA STATE WATER RESOURCES CONTROL BOARD

\title{
California GAMA Program: Sources and transport of nitrate in groundwater in the Livermore Valley Basin, California
}

November, 2005

This work was performed under the auspices of the U.S.

Department of Energy by the University of California,

Lawrence Livermore National Laboratory under contract No.

W-7405-ENG-48.

1980
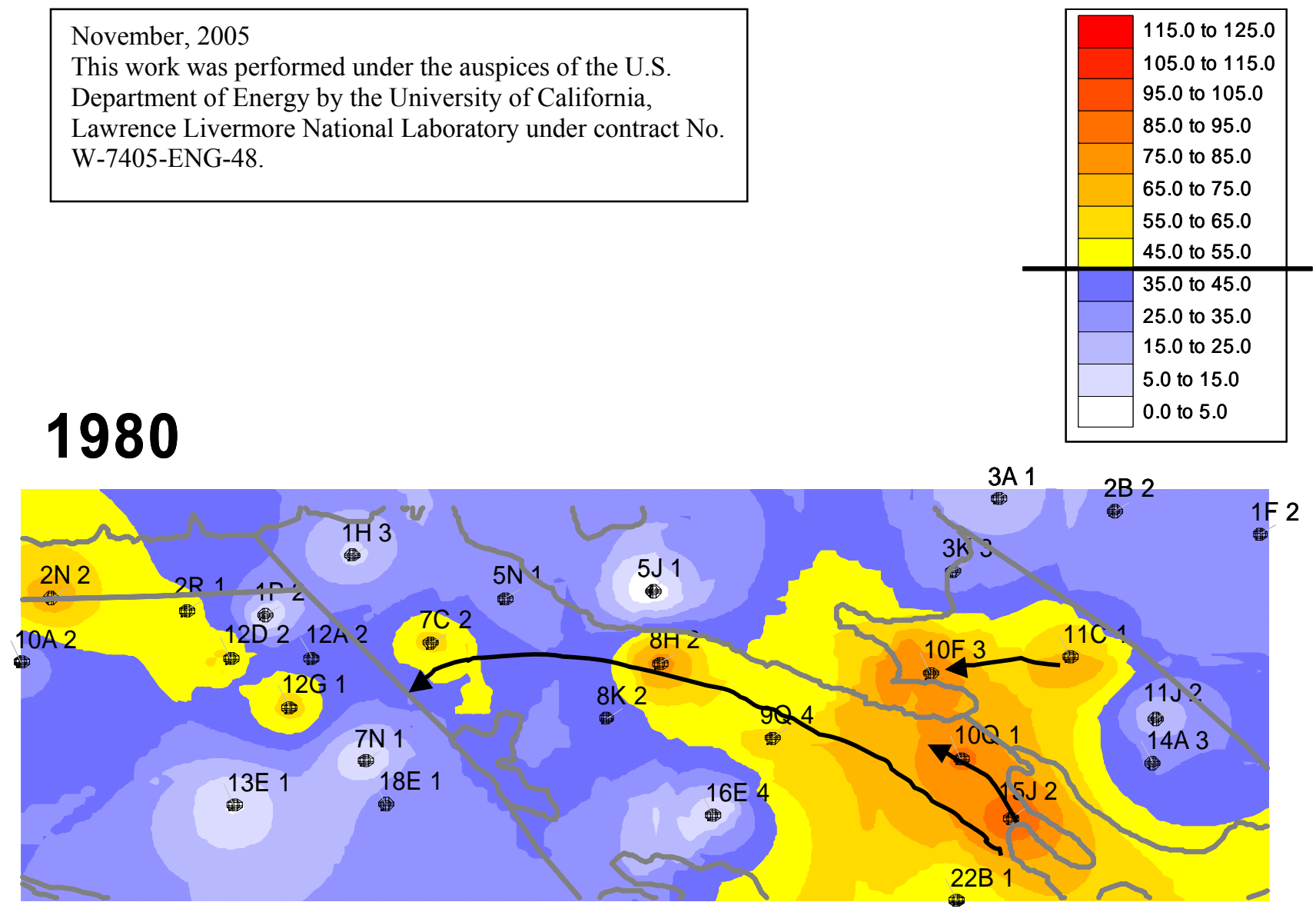
Contributors:

Harry Beller

Gail Eaton

Brenda Ekwurzel

Bradley K. Esser

Qinhong $\mathrm{Hu}$

G. Bryant Hudson

Roald Leif

Walt W. McNab

Cheryl Moody-Bartel

Keara Moore

Jean E. Moran

On the cover: Contoured nitrate concentrations (as $\mathrm{NO}_{3}{ }^{-}$in $\mathrm{mg} / \mathrm{L}$ ) in Livermore Valley groundwater from 1980 water quality data (data courtesy of Zone 7 Water Agency)

Sources and transport of nitrate in groundwater in the Livermore Valley Basin, California 


\section{Executive Summary}

A critical component of the State Water Resource Control Board's Groundwater Ambient Monitoring and Assessment (GAMA) Program is to assess the major threats to groundwater resources that supply drinking water to Californians (Belitz et al., 2004). Nitrate concentrations approaching and greater than the maximum contaminant level (MCL) are impairing the viability of many groundwater basins as drinking water sources Source attribution and nitrate fate and transport are therefore the focus of special studies under the GAMA program. This report presents results of a study of nitrate contamination in the aquifer beneath the City of Livermore, where high nitrate levels affect both public supply and private domestic wells.

Nitrate isotope data are effective in determining contaminant sources, especially when combined with other isotopic tracers such as stable isotopes of water and tritiumhelium ages to give insight into the routes and timing of nitrate inputs to the flow system. This combination of techniques is demonstrated in Livermore, where it is determined that low nitrate reclaimed wastewater predominates in the northwest, while two flowpaths with distinct nitrate sources originate in the southeast. Along the eastern flowpath, $\delta^{15} \mathrm{~N}$ values greater than $10 \%$ indicate that animal waste is the primary source. Diminishing concentrations over time suggest that contamination results from historical land use practices. The other flowpath begins in an area where rapid recharge, primarily of lownitrate imported water (identified by stable isotopes of water and a tritium-helium residence time of less than 1 year), mobilizes a significant local nitrate source, bringing groundwater concentrations above the $\mathrm{MCL}$ of $45 \mathrm{mg} \mathrm{NO}_{3} \mathrm{~L}^{-1}$. In this area, artificial recharge of imported water via local arroyos induces flux of the contaminant to the regional aquifer. The low $\delta^{15} \mathrm{~N}$ value (3.1\%o) in this location implicates synthetic fertilizer. Geochemical modeling supports the hypothesis of separate sources, one including organic carbon, as from animal waste, and one not. In addition to these anthropogenic sources, natural nitrate background levels between 15 and $20 \mathrm{mg} \mathrm{NO}_{3} \mathrm{~L}^{-1}$ are found in deep wells with residence times greater than 50 years.

\section{Introduction and Background}

Nitrate contamination of California drinking water supplies is pervasive- about $10 \%$ of California public drinking water supply wells produce water that exceeds the regulatory drinking water limit, and a much larger fraction produce water which approaches the limit (CA DHS, 2004). Nitrate contamination of groundwater is a growing concern for drinking water supplies not just in California, but also in many areas in the United States. Between 1993 and 2000, the U.S. Geological Survey's National Water-Quality Assessment program found that $9 \%$ of domestic supply wells and $2 \%$ of public supply wells exceeded the Environmental Protection Agency's maximum contaminant level (MCL) for drinking water of $45 \mathrm{mg} \mathrm{NO}_{3} \mathrm{~L}^{-1}\left(10 \mathrm{mg} \mathrm{L}^{-1}\right.$ as $\mathrm{N}$ ) (Nolan et al., 2002). The human activities that contribute nitrate to groundwater - animal operations, crop fertilization, wastewater treatment discharge, septic systems - are ongoing and essential to the industry and commerce of the State of California. Best management practices can mitigate source loading but not eliminate it. Furthermore, nitrate is expensive to remove from drinking water supplies, especially in public and 
private systems that rely on untreated groundwater and do not have the necessary water treatment infrastructure. These factors combine to make nitrate the greatest contaminant threat to California's drinking water supply.

The ultimate goal of the Groundwater Quality Monitoring Act of 2001 (AB599) is the implementation of a comprehensive monitoring program to allow groundwater basin assessment. Assessment is a broad term, but encompasses assessing susceptibility of groundwater to contamination, characterizing current water quality in a basin, and predicting future water quality under different conditions. Because of the potential threat that nitrate poses to drinking water supplies, special studies are focused on basin-scale nitrate contamination. To meet these goals, basin assessment must consider the current inventory of nitrate in basin soils and waters, current and past source loading, groundwater recharge and transport, and nitrogen cycling in the soil, vadose and saturated zone. Nitrate occurs naturally, has relatively low-intensity point, distributed and nonpoint sources, and has a long history of introduction into the environment. Surface nitrogen loading has dramatically increased in the last 50 years, making groundwater ages a useful approach to assessing historical inputs and to determining the effectiveness of relatively recently implemented nitrate management plans.

In many groundwater basins, urbanization has created a growing demand for drinking water, while long histories of agricultural activity have left aquifers potentially at risk from nitrate. Water agencies and regulators can develop more effective management strategies when nitrate sources are well understood. Many past studies have used ${ }^{15} \mathrm{~N}$ and ${ }^{18} \mathrm{O}$ in nitrate as tracers of the source and fate of contamination (Kendall and Aravena, 2000). This dual isotope technique is sometimes limited by the overlap of source isotope values and by the variety of potential processes that affect nitrate (Aravena et al., 1993; Mengis et al., 2001). Successful studies of nitrate behavior and distribution must take into account the many environmental and historical factors that affect nitrate fate and transport (Bohlke and Denver, 1995).

Our purpose is to improve upon traditional nitrate investigation methods that often yield ambiguous interpretations. We apply an integrated analytical approach using multiple lines of evidence to resolve the manifold origins and pathways of nitrate contamination. This approach is demonstrated in Livermore, CA, a city that relies on groundwater for a significant portion of its drinking water, but where MCL exceedances have occurred at 6 of the 13 public supply wells in the contaminated portion of the basin. As in many regions where this approach may be beneficially applied, Livermore has a decades long history of varied nitrate inputs in a complex groundwater system.

Previous studies of Livermore's nitrate problem have estimated nitrate loading from various sources using literature ranges of potential nitrate inputs from these sources (Steinbergs and Wong, 1980; Raines, Melton, and Carella, Inc., 2002). These assessments consider only theoretical calculations of modern inputs and do not account for residual inputs or for the effects of hydrogeology. In our study, we incorporate these factors by interpreting nitrate isotope and concentration data in the context of local hydrogeology and land use history. We explore nitrate interactions along flowpaths using geochemical modeling and we analyze dissolved gases to determine whether saturated-zone denitrification has taken place. Additionally, other isotopic tracers such as stable isotopes of water and tritium-helium residence times give valuable insight into the routes and timing of various nitrate contributions to the flow system. 


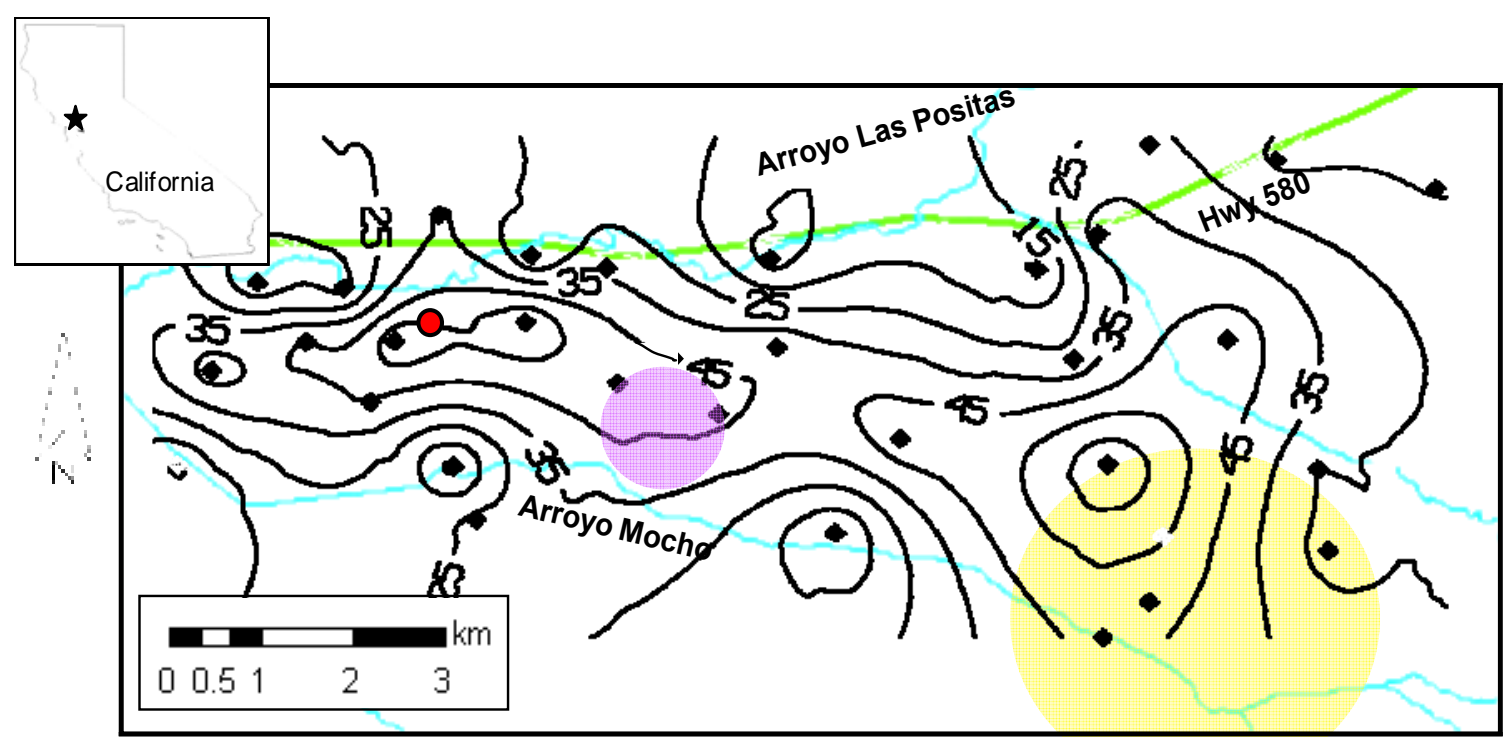

- Well used in nitrate contour

Region of high drinking water extraction

Water-bearing alluvial deposits

Livermore Wastewater Reclamation Plant

Multiple nitrate inputs include septic tanks, fertilized vineyards, livestock, and grassland

Figure 1. Nitrate concentrations in Livermore Valley. Approximate nitrate contours, in $\mathrm{mg} / \mathrm{L}$, kriged using RockWare ${ }^{\mathbf{T M}}$. Wells used to draw contours have depths less than $35 \mathrm{~m}$, the approximate depth of a non-continuous aquiclude and thus the defined cutoff for the aquifer's shallow zone. The apparent gap in the center of the map is an artifact of the limitations of the data, rather than a break in the plume.

This study demonstrates the application of an integrated analytical approach in a nitrate-impacted groundwater basin. Interpretation of nitrate ${ }^{15} \mathrm{~N}$ and ${ }^{18} \mathrm{O}$ data to identify contamination sources is enhanced through the use of additional isotopic and chemical tracers. We use well water major ion analyses to delineate the extent of the high nitrate region, and use historical data, collected for nitrate monitoring purposes, to track concentration changes through time. Stable isotopes of water provide information about groundwater sources, and residence time methods using tritium and noble gas measurements further constrain the source history. Possible reactions of nitrate are accounted for by analysis of dissolved gases, which can indicate whether saturated-zone denitrification has taken place. The methods used here could be widely applied in the many groundwater basins where urbanization has created a greater demand for drinking water, and where decades of agricultural activity have left a potential source of nitrate to groundwater. 


\section{Site Description and Land Use History}

Multiple potential nitrate sources in the Livermore Valley from both past and present land uses make it an ideal setting for a multi-tracer geochemistry approach. Nitrate monitoring programs identified two locations of particular concern as possible origins of contamination. Around the Livermore Wastewater Reclamation Plant (LWRP), treated wastewater is used in irrigation. In the 1980s, contributions from LWRP were identified as the cause of high levels of nitrate in groundwater in that area (Sylvester, 1983). Subsequently, wastewater treatment methods were upgraded to include a tertiary treatment step that induces denitrification and reduces nutrient concentrations considerably. In 2003, the average monthly nitrate concentration in the applied water was only $4.9 \mathrm{mg} \mathrm{L}^{-1}$ (pers. comm., D. Atkins).

The other area of concern is the unincorporated southeast region of the valley (Figure 1). Past monitoring data show that as early as 1980, a nitrate plume originating in this location extended at least to the area where most groundwater extraction for drinking water takes place (Figure 1 and cover figure; unpublished data, Zone 7, 2003). A number of possible nitrate contamination sources exist in the southeast. Several reports in the past have implicated septic leachate as a primary nitrate source (Sylvester, 1983; Sorenson et al., 1984; Raines, Melton, and Carella, Inc., 2002). In this unsewered area, approximately 100 residences have septic systems, a number that has not changed significantly in the past 30 years (Raines, Melton, and Carella, Inc., 2002). Another possible source is livestock waste from both modern and historical inputs. For many decades, ending in the early 1970 s, poultry farming was a significant operation in this area. Over the last century, various grazing operations have existed on the grassland to the south and east of this area (Raines, Melton, and Carella, Inc., 2002).

This southeast region also includes vineyards which have increased in acreage over the last several decades to the current area of approximately $8 \mathrm{~km}^{2}$ (Raines, Melton, and Carella, Inc., 2002). Although vineyards tend to use less nitrogen fertilizer than vegetable crops, they can still contribute significant nitrate to groundwater. One recent report found groundwater nitrate concentrations of up to $61.6 \mathrm{mg} \mathrm{L}^{-1}$ beneath grape fields in the San Joaquin Valley, CA (Burow, et al., 1998), while another demonstrated that, even with closely controlled drip irrigation, $67 \%$ to $79 \%$ of fertilizer nitrogen applied to vineyards in the spring remained in the soil at harvest time, available for leaching with winter rains (Hajrasuliha, 1998).

Another possible nitrate source in the valley is that formed from the oxidation of organic nitrogen, naturally found in soil as a result of plant decomposition and microbial activity (Kendall and Aravena, 2000). Natural nitrate concentrations in groundwater below temperate region grasslands, unimpacted by anthropogenic activities, are generally below $9 \mathrm{mg} \mathrm{L}^{-1}$ (Edmunds and Gaye, 1997). In arid and semiarid regions where denitrification is unlikely, however, greater amounts of natural nitrate can accumulate in soils and be available for leaching to groundwater (Edmunds and Gaye, 1997; Brenner et al., 2001; Bohlke, 2001). In Livermore's climate and habitat, leguminous vegetation that supports nitrogen-fixing bacteria is an important potential nitrate source. Burr clover and vetch, species that produce between 90 and $200 \mathrm{~kg} \mathrm{ha}^{-1} \mathrm{y}^{-1}$ of nitrate (National Research Council, 2001), thrive in Livermore during warm, wet winters (Steinbergs and Wong, 1980). It is often assumed that nitrate produced by legumes is balanced by denitrification 
(Steinbergs and Wong, 1980), but in Livermore's dry summer season, it is possible that there is not enough soil moisture to support denitrification of this large quantity of nitrate. A study in a North African region with a similar semiarid climate attributed groundwater nitrate levels as high as $250 \mathrm{mg} \mathrm{L}^{-1}$ to nitrogen fixed by legumes (Edmunds and Gaye, 1997).

\section{METHODS}

\section{Sample Collection}

The thirty-two well sampling locations are shown in Figure 2. At Zone 7, Las Positas Golf Course and LWRP monitoring wells, samples were taken using a portable submersible pump. At private domestic wells and California Water Service Company supply wells, dedicated well pumps were used. Most ion and isotope samples were filtered in the field with a $0.45 \mu \mathrm{m}$ in-line filter. Nitrate isotope samples were loaded onto anion exchange columns within 24 hours of sampling at LLNL, and ion analyses were performed within 48 hours of sampling. For excess nitrogen analyses, dissolved gases (nitrogen, oxygen, and argon) were collected in $40-\mathrm{mL}$ vials (VWR TraceClean ${ }^{\mathrm{TM}}$, amber borosilicate; 0.125 -inch septum liner) with no headspace. Samples were stored in coolers on ice and analyzed within 24 hours of sampling. A 1-L Pyrex bottle with a polypropylene plug seal cap was filled for tritium analysis and a 30-mL clear, Frenchsquare type glass bottle with a Qorpak ${ }^{\mathrm{TM}}$ polyseal-lined cap was filled for analysis of stable isotopes $\mathrm{O}$ and $\mathrm{H}$ in water. Approximately $10 \mathrm{~mL}$ of groundwater was collected in copper tubes pinched by metal clamps for noble gas samples.

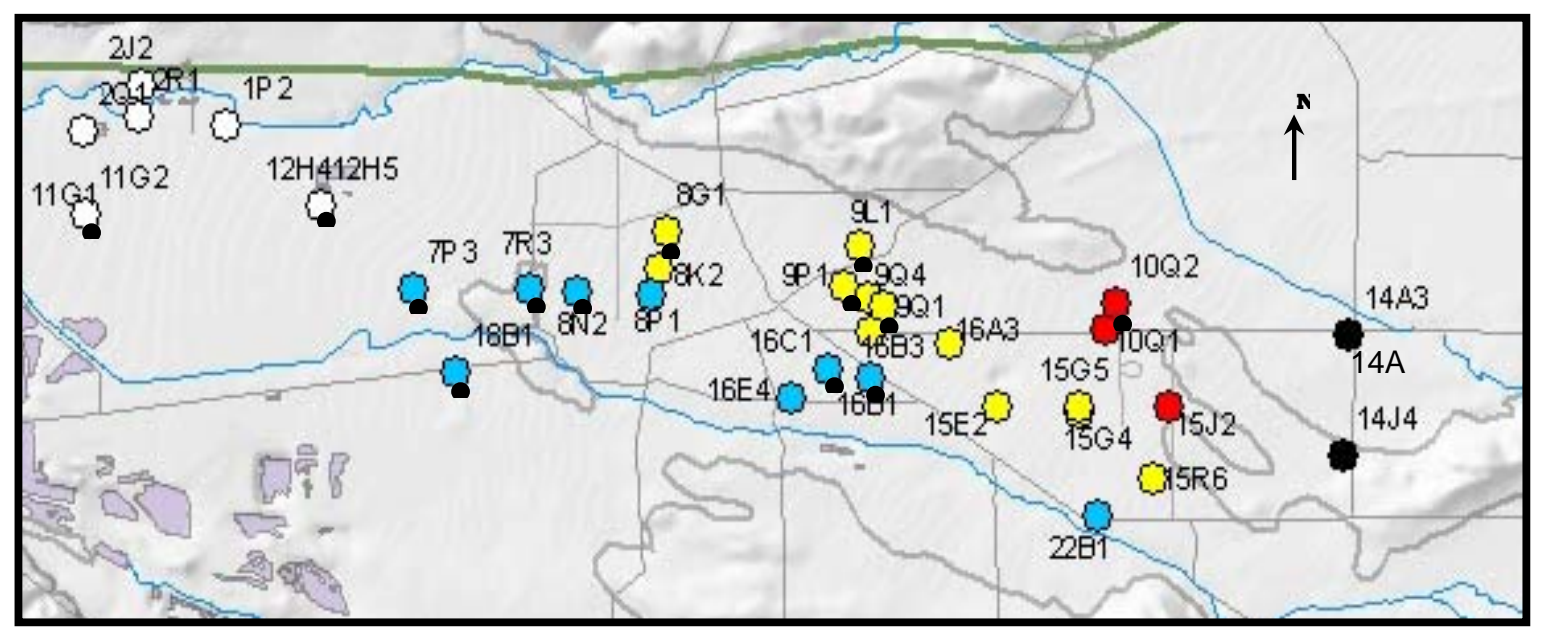

Figure 2. Map of the east side of the Livermore Basin showing wells sampled for the study. Color codings are related to geochemical and geographic groupings described in the text. 


\section{Laboratory Methods}

Nitrate isotope samples were analyzed at the Environmental Isotopes Lab at the University of Waterloo, all other analyses were performed at LLNL. After extraction as silver nitrate, nitrogen gas for the measurement of $\delta^{15} \mathrm{~N}$ was produced by the sealed tube $\mathrm{Cu}$ /copper oxide method (Kendall and Grim, 1990; Flatt and Heemskerk, 1997) and $\mathrm{CO}_{2}$ for measurement of $\delta^{18} \mathrm{O}$ was produced by combustion with graphite. The isotope ratios of these gases were measured on a PRISM isotope ratio mass spectrometer. $\delta^{15} \mathrm{~N}$ results are reported as per mil relative to AIR and $\delta^{18} \mathrm{O}$ results are referenced to VSMOW. Anions and cations were measured by ion chromatography on a Dionex IC DX-600 with a precision of $\pm 2.7 \%$ relative standard deviation for nitrate. Oxygen isotopes of water were measured on a VG PRISM isotope ratio mass spectrometer. Results are reported as per mil with reference to VSMOW and have a precision of $\pm 0.1 \%$. Deuterium was measured on the VG PRISM after extraction of hydrogen by the zinc reduction technique. Results are reported as per mil with reference to VSMOW and have a precision of $\pm 0.9 \%$. Dissolved gases for examination of excess nitrogen were measured by membrane inlet mass spectrometry (MIMS) with an SRS RGA200 quadrupole mass spectrometer (Kana et al., 1994). ${ }^{3} \mathrm{He}$ and ${ }^{4} \mathrm{He}$ were measured on a VG5400 mass spectrometer, Ar was measured using a high-sensitivity capacitive manometer, and $\mathrm{Ne}$, $\mathrm{Kr}$, and Xe were measured on an SRS RGA200 quadrupole mass spectrometer. Tritium was determined by measuring the rate of ${ }^{3} \mathrm{He}$ accumulation. Residence time calculations were made by combining measurements of tritium with measurements of its decay product, ${ }^{3} \mathrm{He}$, and excess air was determined from measured Ne concentrations. In this calculation, noble gas data was used to separate tritiogenic helium from that from other sources (Ekwurzel, 2004).

\section{Isotope and Dissolved Gas Techniques}

A variety of nitrate fractionation processes lead to unique isotopic signatures for different nitrate sources. As a result, isotope values of nitrogen and oxygen can be useful in identifying the origin of groundwater nitrate (Figure 3). Synthetic fertilizers generally have $\delta^{15} \mathrm{~N}$ values between $-2 \%$ and $+4 \%$ (Kendall et al., 1998). By the time it reaches the groundwater, however, fertilizer nitrogen tends to be enriched by several per mil over the original source, often making it indistinguishable from soil organic nitrogen, which tends to have $\delta^{15} \mathrm{~N}$ values of $+3 \%$ to $+8 \%$ (Bohlke and Denver, 1995). Due to volatile loss of ammonia from manure, nitrate from animal waste has higher $\delta^{15} \mathrm{~N}$ values, usually greater than $+10 \%$, and so can often be distinguished from other sources. All animals produce waste with similar $\delta^{15} \mathrm{~N}$ values, though, so isotopes alone are usually not useful in differentiating between septic waste and other animal wastes (Kendall, 1998; Choi et al., 2003). 


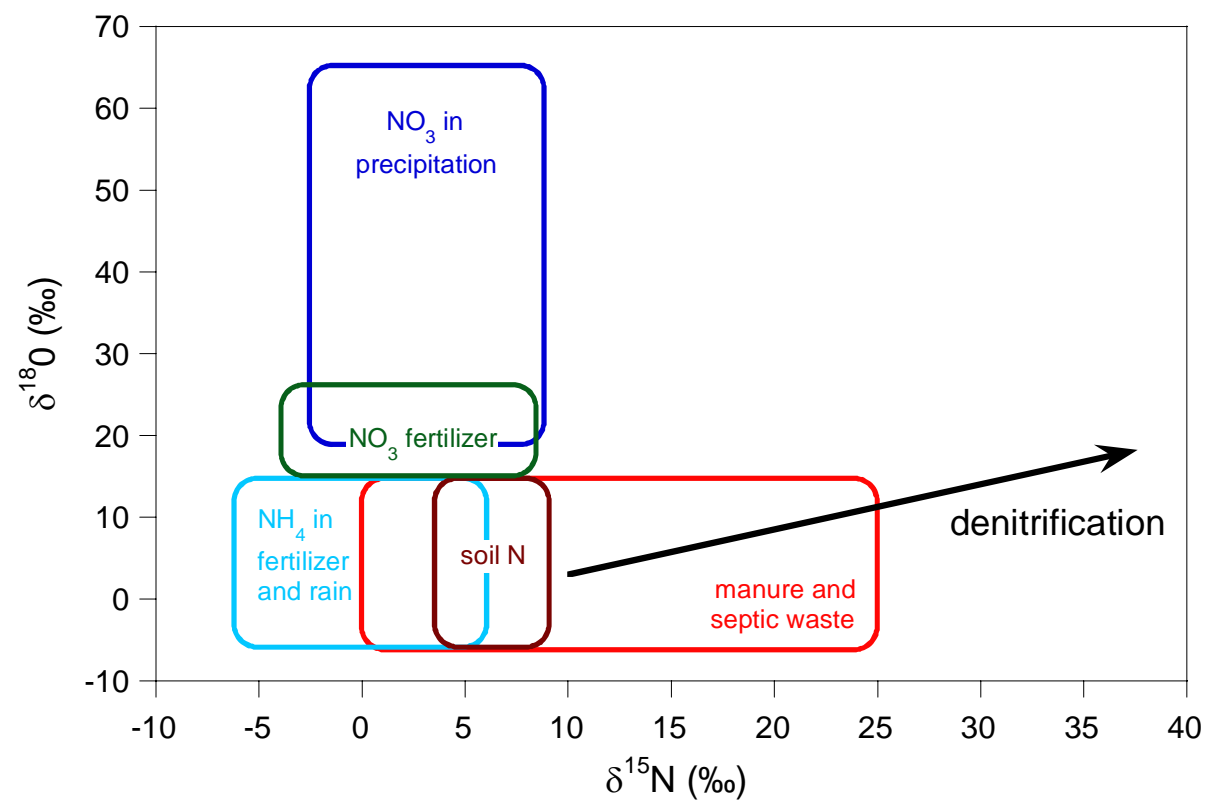

Figure 3: Isotopic composition of nitrogen and oxygen in nitrate from different sources (after Kendall, 1998).

Oxygen isotope values of nitrate can help clarify source identification, especially to separate nitrate fertilizer input from other sources, which produce nitrate by nitrification of ammonium or organic nitrogen. The $\delta^{18} \mathrm{O}$ in nitrate fertilizers has a value close to the atmospheric value of $+23 \%$. Other sources of nitrate incorporate two oxygen atoms from water and one from dissolved oxygen gas, leading to lighter $\delta^{18} \mathrm{O}$ values dependent on the oxygen isotopes in the water (Kendall and Aravena, 2000). Nitrate from ammonium nitrate fertilizers will have $\delta^{18} \mathrm{O}$ values that reflect both processes (Aravena et al., 1993).

Nitrate isotope data are also valuable as indicators of the occurrence of denitrification; as denitrification occurs, nitrogen and oxygen in nitrate are enriched in a characteristic 2:1 ratio (Kendall, 1998). Saturated zone denitrification can also be identified by the presence of its end product, excess nitrogen, dissolved in groundwater. Atmospheric nitrogen is distinguished from excess nitrogen by comparison with dissolved argon, the dominant source of which is atmospheric (Kana et al., 1994; Vogel et al., 1981). We employ both methods to check for possible denitrification.

\section{Geochemical Modeling}

Geochemical modeling was carried out using the inverse modeling capabilities of the U.S. Geological Survey's PHREEQC geochemical model (Parkhurst and Appelo, 2002) to identify interphase mass transfer reactions that reconcile elemental mass balances and charge balances in representative nitrate-impacted and background groundwater compositions (major cations, anions, and $\mathrm{pH}$ ) along both the manure flowpath and the alluvial channel flowpath (Figure 4). 


\section{0}

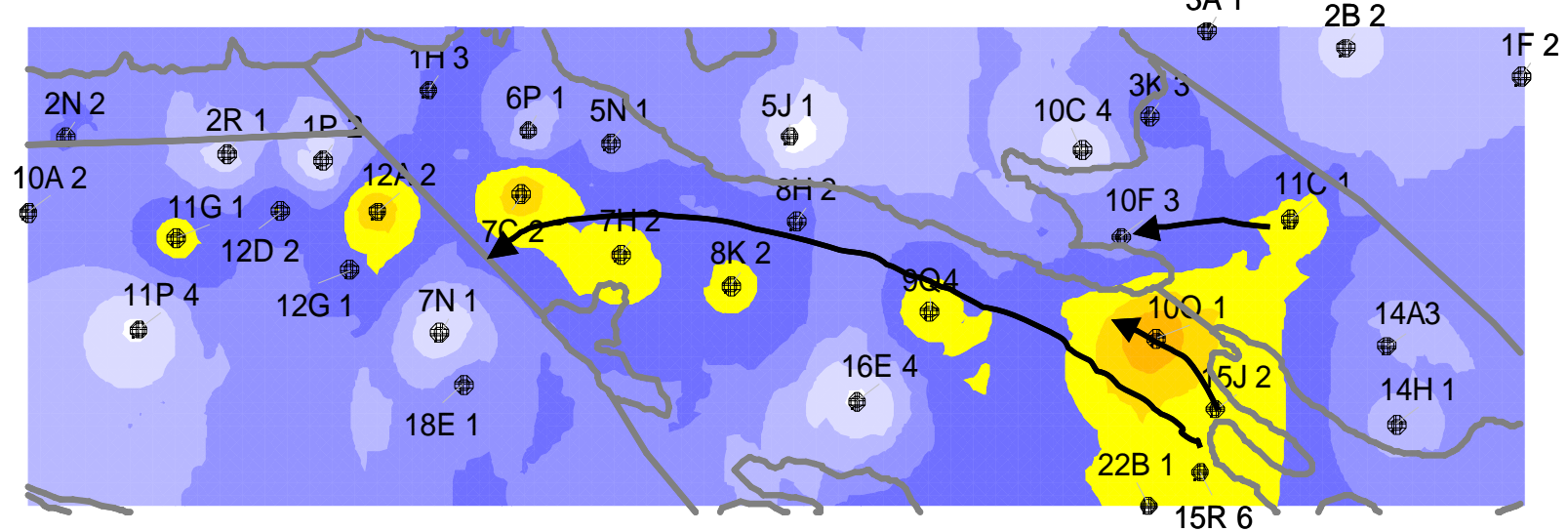

Figure 4. Nitrate contours drawn from the extensive, historical water quality dataset from Zone 7 (data shown are from 2000). Arrows indicate flowpaths discussed in the text.

The first step in implementing such an inverse modeling approach is the definition of contaminant-free and maximally contaminant-impacted end-member water compositions for each flowpath. Ideally, this is accomplished via extrapolation of best-fit linear relationships between geochemical parameter values and corresponding nitrate concentrations using all historical data from all wells along a flowpath. The parameter values associated with the estimated nitrate background $\left(15 \mathrm{mg} \mathrm{L}^{-1}\right)$ and the nitrate peak are then assigned to the idealized contaminant-free and maximally contaminant-impacted end-members.

This method was only possible for $\mathrm{pH}$ and cations along the manure flowpath. In the other, non-ideal situations, end-members were constructed based on the following assumptions. For anions along the manure flowpath, the historical low-nitrate measurement at the upgradient well was taken to represent the contaminant-free endmember, while the historical high-nitrate measurement from the downgradient well was used as the contaminant-impacted end-member.

Along the alluvial channel flowpath, groundwater is subject to multiple nitrate inputs and mixing processes, so modeling was limited to the initial portion of the flowpath. Well 16A3, a downgradient monitoring well located in the highest concentration part of the nitrate plume, and for which historical data were available, was used to establish the maximally contaminant-impacted end-member. Because most parameters at this location were relatively stable, end-member values were based on averaged rather than extrapolated data. Due to the severity of the contamination along this flowpath, none of the historical data were acceptable to represent a nitrate-free endmember. Instead, two non-plume wells with environmental characteristics similar to those of the flowpath's source region were selected as surrogates for the upgradient well. Data from these wells were extrapolated to determine the contaminant-free end-member.

Historical averages of parameters at a deep, tritium-dead well and from an SBA monitoring station were estimated as potential inputs from these water sources. While these water compositions do not represent true collinear end-members along groundwater flowpaths, they do represent contrasting water compositions for each of the respective 
flowpaths that presumably integrate the effects of the geochemical processes associated with nitrate loading. Putative phases involved in the mass transfer reactions include a nitrogen source $\left(\mathrm{NH}_{3}\right)$; organic carbon associated with animal fertilizer or septic tank leachate (idealized as $\mathrm{CH}_{2} \mathrm{O}$ ); carbonate minerals $\mathrm{CaCO}_{3}$ and dolomite $\left(\mathrm{CaMg}\left(\mathrm{CO}_{3}\right)_{2}\right)$; possible soil amendments dolomite, gypsum $\left(\mathrm{CaSO}_{4} \cdot 2 \mathrm{H}_{2} \mathrm{O}\right)$, and $\mathrm{KCl}$; ion exchangers ( $\mathrm{NaX}, \mathrm{KX}, \mathrm{MgX}_{2}, \mathrm{CaX}_{2}$ ); and $\mathrm{O}_{2}$, required to oxidize both $\mathrm{NH}_{3}$ and $\mathrm{CH}_{2} \mathrm{O}$. These phases were selected for the PHREEQC inverse model with the added constraints that $\mathrm{NH}_{3}$, $\mathrm{CH}_{2} \mathrm{O}$, gypsum, $\mathrm{KCl}$, and $\mathrm{O}_{2}$ could only be utilized as reactants, not products. The same constraint was placed on dolomite, $\mathrm{CaMg}\left(\mathrm{CO}_{3}\right)_{2}$, as its precipitation kinetics are regarded as extremely slow (Morse and Mackenzie, 1990).

\section{RESULTS AND DISCUSSION}

Nitrate-source data is most successfully interpreted in the context of the constraints that can be placed on the groundwater flow system using conventional hydrogeological data along with other isotopic and geochemical tracers. Nitrate concentrations are highest in the southeast part of the study area, where many of the wells exceed the MCL (Table 1). The contamination extends to the area of major groundwater extraction as shown in the contour map in Figure 1. In conjunction with the estimated flowpaths, this supports the conclusion of past studies that the most significant nitrate contamination originates in the southeastern recharge area. Current and historical data consistently record higher nitrate concentrations in shallow monitoring wells than in deep wells, suggesting a plume with a shallow core. Nitrate concentrations identify the problem regions but are not diagnostic for distinguishing among competing sources or for helping identify historic or contemporary land use practice culpability. The following methods are used to identify nitrate source(s), to examine in detail the possibility of denitrification, and to delineate nitrate transport on the sub-basin scale.

\section{Excess Nitrogen}

The possibility of saturated zone denitrification must be considered before any conclusions can be drawn based on nitrate concentrations or nitrate isotope values. Samples for which noble gas data are available have recharge temperatures calculated to be between 11.8 and 21.6 C (Table 1). All nitrogen to argon ratios fall within the general range delineated for these temperatures by equilibrium solubilities and excess air trends, indicating that excess nitrogen is not present (Figure 5). Although these results do not exclude the possibility of denitrification before transport to the water table, they demonstrate that saturated zone denitrification is not an important process. This result is consistent with low dissolved organic carbon $(<1.5 \mathrm{mg} / \mathrm{L} \mathrm{n}=9)$ and high dissolved oxygen concentrations that indicate an aerobic system with low reduction potential and lack of an electron donor. Groundwater nitrate data, therefore, may be interpreted directly as indicative of nitrate source, without accounting for attenuation or isotopic enrichment due to denitrification along the flowpath. 


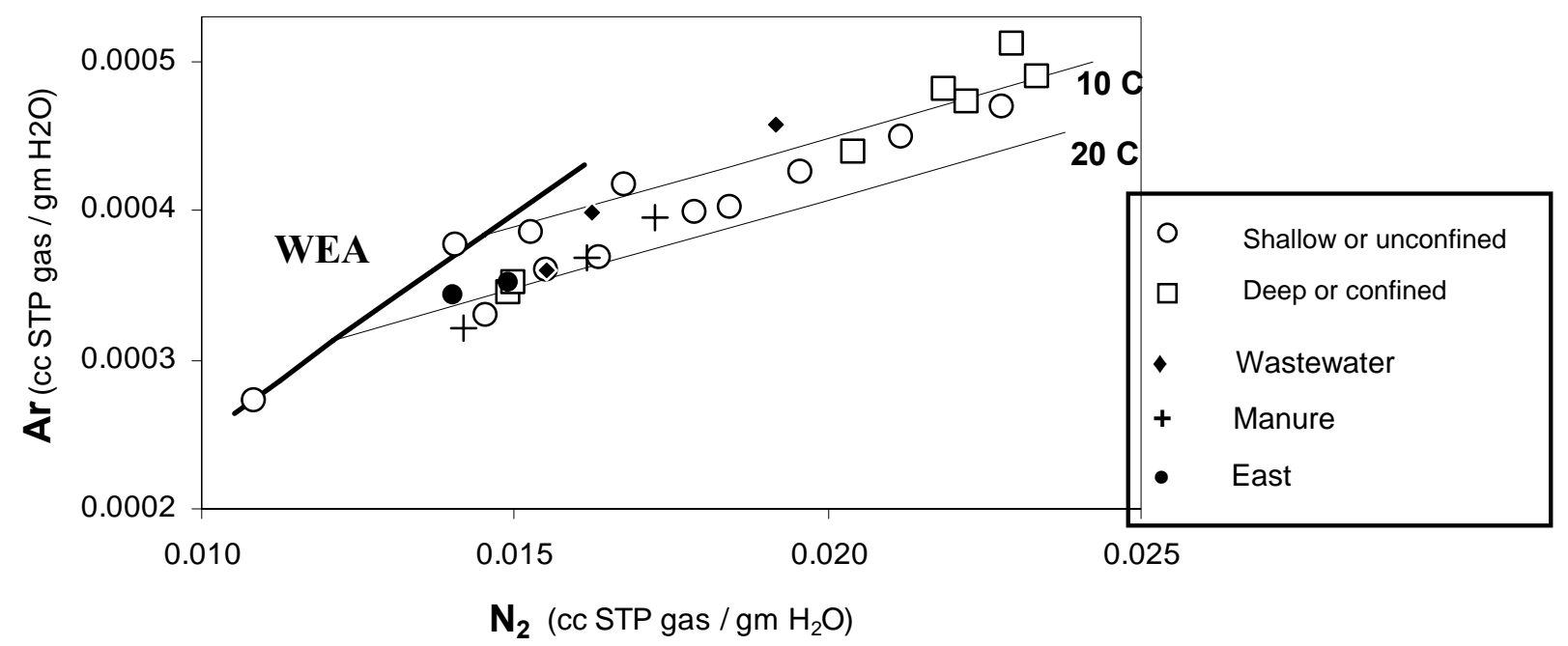

Figure 5. Dissolved nitrogen versus dissolved argon. The WEA ("water equilibrated with air") line represents the nitrogen and argon ratio expected based on equilibrium solubilities of the gases. The excess air lines are projected by assuming that excess air is the result of complete dissolution of entrapped air bubbles. All samples fall, within error, on or above the projected region of ratios for dissolved excess air. Any samples above this region likely experienced partial air bubble dissolution during recharge.

\section{Groundwater Sources}

We use stable isotopes of water to establish groundwater provenance. The $\delta^{18} \mathrm{O}$ and $\delta^{2} \mathrm{H} 2003$ data fit onto a trendline falling slightly below the Global Meteoric Water Line with a slope generally parallel to it, suggestive of a local meteoric water line trend (Figure 6). The nearest station for which long term precipitation data have been collected is in Santa Maria, CA (GNIP, 2004) $400 \mathrm{~km}$ to the south. The Livermore data fall within the general range defined by Santa Maria precipitation isotopes, although the Livermore groundwater's $\delta^{18} \mathrm{O}$ and $\delta^{2} \mathrm{H}$ values are somewhat lighter due to its higher elevation and inland location. Adherence to a Local Meteoric Water Line (LMWL) without significant deviation provides evidence that this groundwater experienced little evaporation prior to recharge.

These isotopic data are also useful in distinguishing between the three most probable sources of water to the aquifer: precipitation, imported South Bay Aqueduct (SBA) water, and ambient groundwater old enough to predate California's history of large-scale water manipulation. Originating mostly at higher elevations in the Sierra Nevada Mountains, SBA water is isotopically lighter than local precipitation. SBA water recharges the aquifer along Arroyo Mocho from April to November and also makes up $95 \%$ of irrigation water and approximately $80 \%$ of domestic water in the area (Segura, 2004). Older ambient groundwater, identified by its lack of tritium, appears at the heavier end of the observed trend. The various mixing fractions of the three 


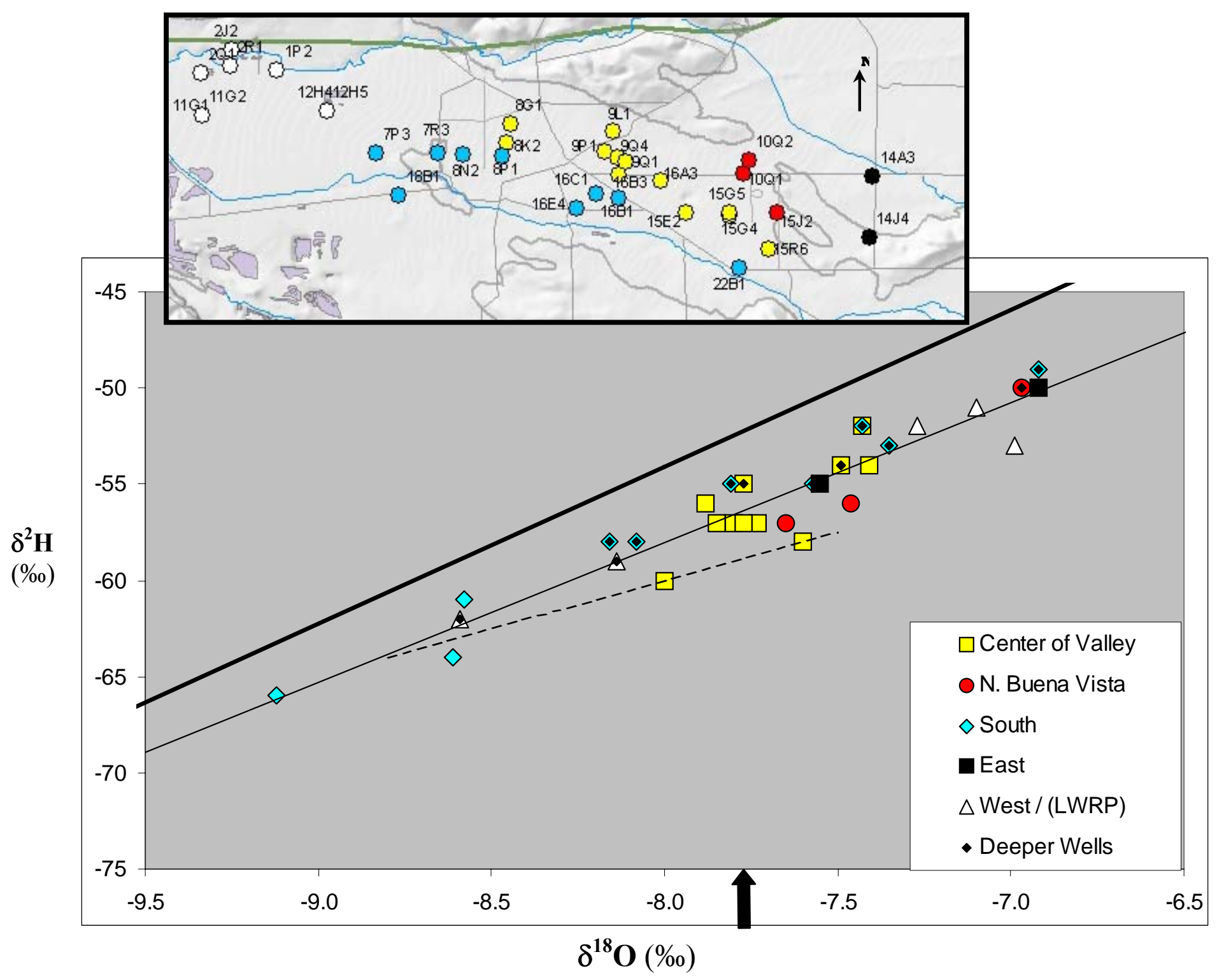

Figure 6. Well water samples fall on a line subparallel to the global meteoric water line in $\delta^{18} \mathrm{O}$ versus $\delta^{2} \mathrm{H}$ space. The mean $\delta^{18} \mathrm{O}$ value measured in Livermore precipitation is shown by the arrow. Samples in the southern (blue symbol) group have lighter stable isotope values and a significant component of imported South Bay Aqueduct water.

possible sources of water are evident in the isotope data, but the large range observed in local precipitation ( -14.8 to $-0.3 \%$ o $\delta^{18} \mathrm{O}$ with a mean of -7.75 ; pers. comm., T. Rose) prevents quantitative determination of the three fractions (Figure 6). In general, local precipitation is a dominant source, and the shallow and proximal wells to Arroyo Mocho (i.e. wells 22B1, 16E4) contain higher fractions of SBA water, while deeper wells (i.e. wells 10Q2, 7P3) have high fractions of older groundwater.

The groundwater flow system can be further constrained by defining the recharge area using tritium-helium residence time data, with the youngest ages representing locations of most recent recharge (Figure 7). The shallow wells nearest the arroyo have 
residence times of less than one year, and most other shallow wells have residence times of less than ten years. These data suggest diffuse recharge throughout the study area with substantial recharge and relatively rapid groundwater flow along the arroyo. Along the coarse sediments of the alluvial channel, there is a general correlation between midscreen well depth and groundwater mean residence time. Even the deepest alluvial channel well (well 9Q1), however, has a significantly higher fraction of young water than the tritium-free deep western wells that are protected by a series of clay layers (wells 7P3 and 7R3). The primary sources of modern recharge, SBA water and precipitation, are both very low in nitrate and cannot be directly implicated as nitrate sources (State of California, 2004). As discussed in more detail below, recently recharged water with high nitrate concentration has likely entrained nitrate that has accumulated in the vadose zone.

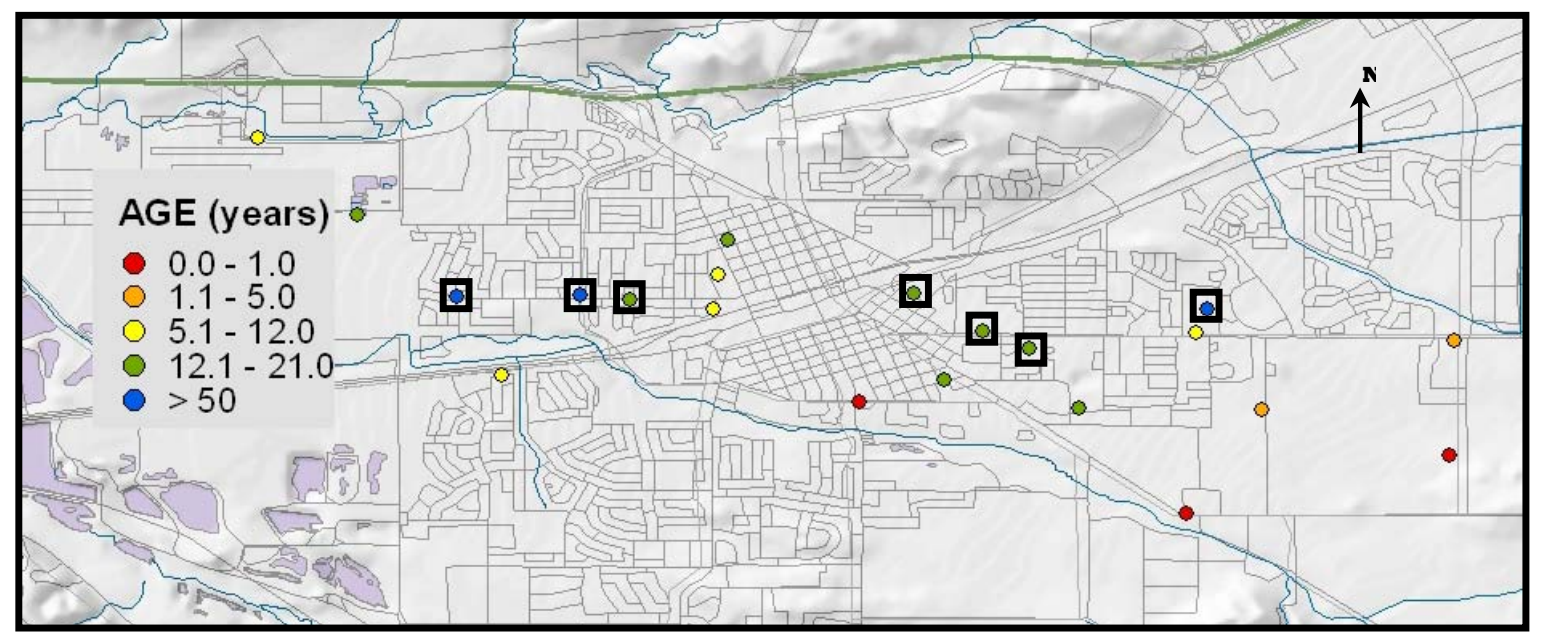

Figure 7. Groundwater ages calculated using the tritium-helium method show very recently recharged water in wells close to the arroyo and on the eastern margin of the basin. Symbols with squares are wells with depths greater than $35 \mathrm{~m}$, which in general have older ages.

\section{Groundwater Chemistry}

Measurement of additional ion concentrations allows for separation of the nitrate plume into well-defined spatial groups based on differing solute composition. A plot of chloride vs. sulfate shows that data from $71 \%$ of the wells lie along a constant ratio trend, indicating the similarity of water type and ion source in these wells (Figure 8). This main trend includes the wells along the alluvial channel flowpath and south to Arroyo Mocho. In the southeast, a relatively high chloride to sulfate ratio separates wells $10 \mathrm{Q} 1$ and $15 \mathrm{~J} 2$ from the rest of the wells in that region, which follow the main trend. Ion data from wells around the LWRP wastewater application area form a distinct lower slope trend, establishing that these wells are dominated by a different water source than the rest of the study area. The low ion end-member of this LWRP trend is defined by the area's deeper, confined wells. These wells have a chloride to sulfate ratio matching that of the main trend, suggesting that the water source impacting the shallow wells does not reach the lower aquifers. Eastern well 14J4, drilled into bedrock rather than alluvium, does not fit into any of the established trends. Wells $14 \mathrm{~J} 4$ and 14A3 lie in a separate subbasin with different hydrogeological conditions and do not follow data trends observed in the rest of 
the valley. For completeness, data were collected and are presented for these wells, but they will not be discussed further.

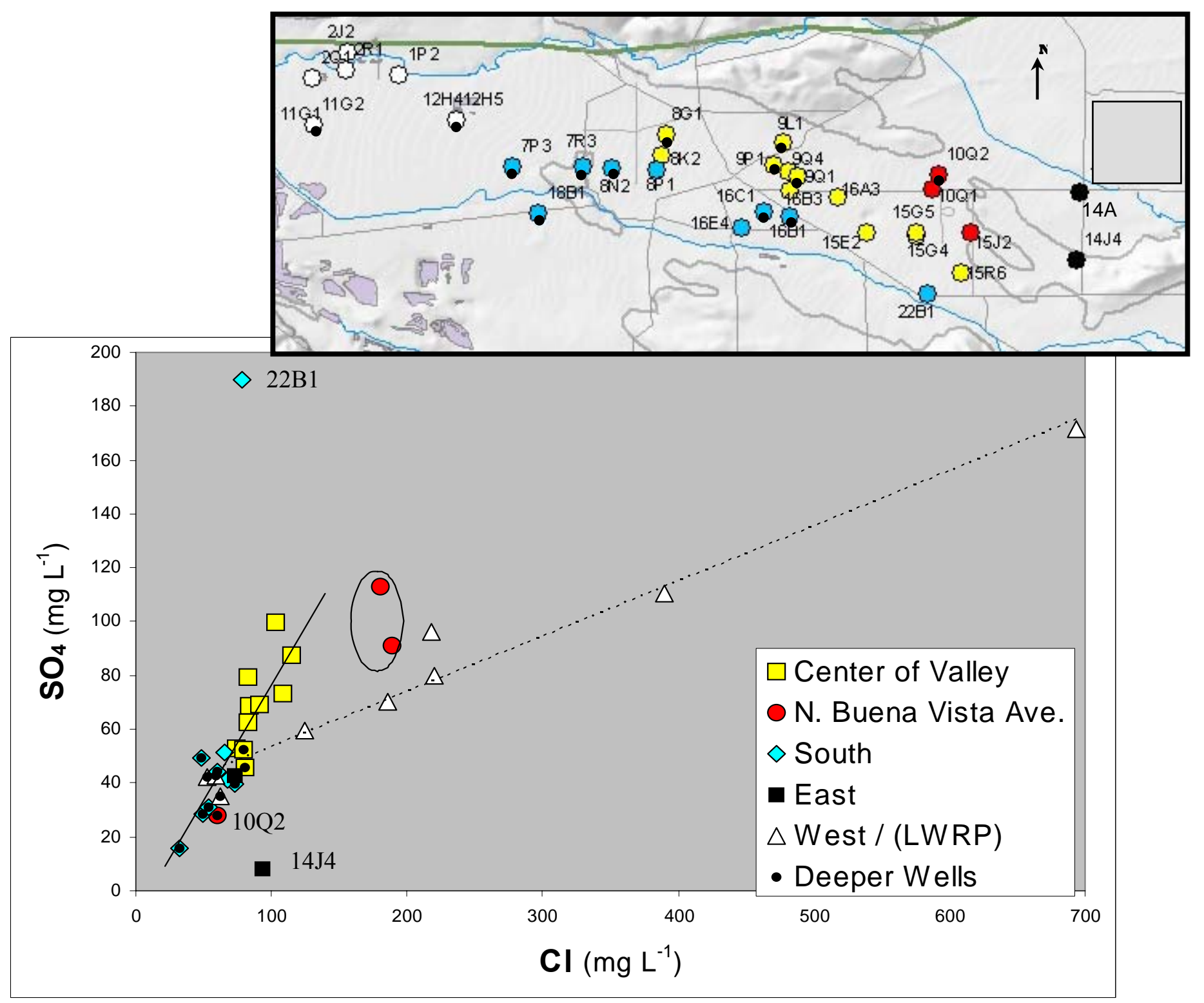

Figure 8. Chloride vs. sulfate compositions. Three spatially distinct water types have been distinguished. Wells within the oval (15J2 and 10Q1) are discussed under the manure source discussion section. 


\section{Nitrate Sources}

\section{Applied Wastewater}

The three distinct groups defined by major ion data as well as by spatial distribution will be further considered individually. In the northwest region around the LWRP, nitrate isotope data confirm that the shallow wells here have a different nitrate source than in the rest of the study area (Figure 9). Shallow nitrate- $\delta^{15} \mathrm{~N}$ values are between $13.0 \%$ and $29.2 \%$, in the range expected for treated wastewater effluent (Jordan et al., 1997; Griggs et al., 2003), and nitrate- $\delta^{18} \mathrm{O}$ values are the highest of all measured samples, consistent with the effects of wastewater processing (Figure 9b). These data signify that irrigation with reclaimed wastewater is the source of this area's distinctive geochemical signature. Water in the deeper wells, unimpacted by irrigation, has nitrate$\delta^{15} \mathrm{~N}$ values $(6.7 \%$ o to $8.8 \%$ ) comparable to the other wells that define the main trend in Figure $9 \mathrm{~b}$. Stable isotopes of water provide further evidence that the confining layers have prevented applied wastewater from reaching the deeper aquifers; water from these aquifers has an isotopic signature suggesting a precipitation source, while samples from the unconfined layer have heavier $\delta^{2} \mathrm{H}$ and $\delta^{18} \mathrm{O}$ values, likely the result of fractionation during wastewater processing.

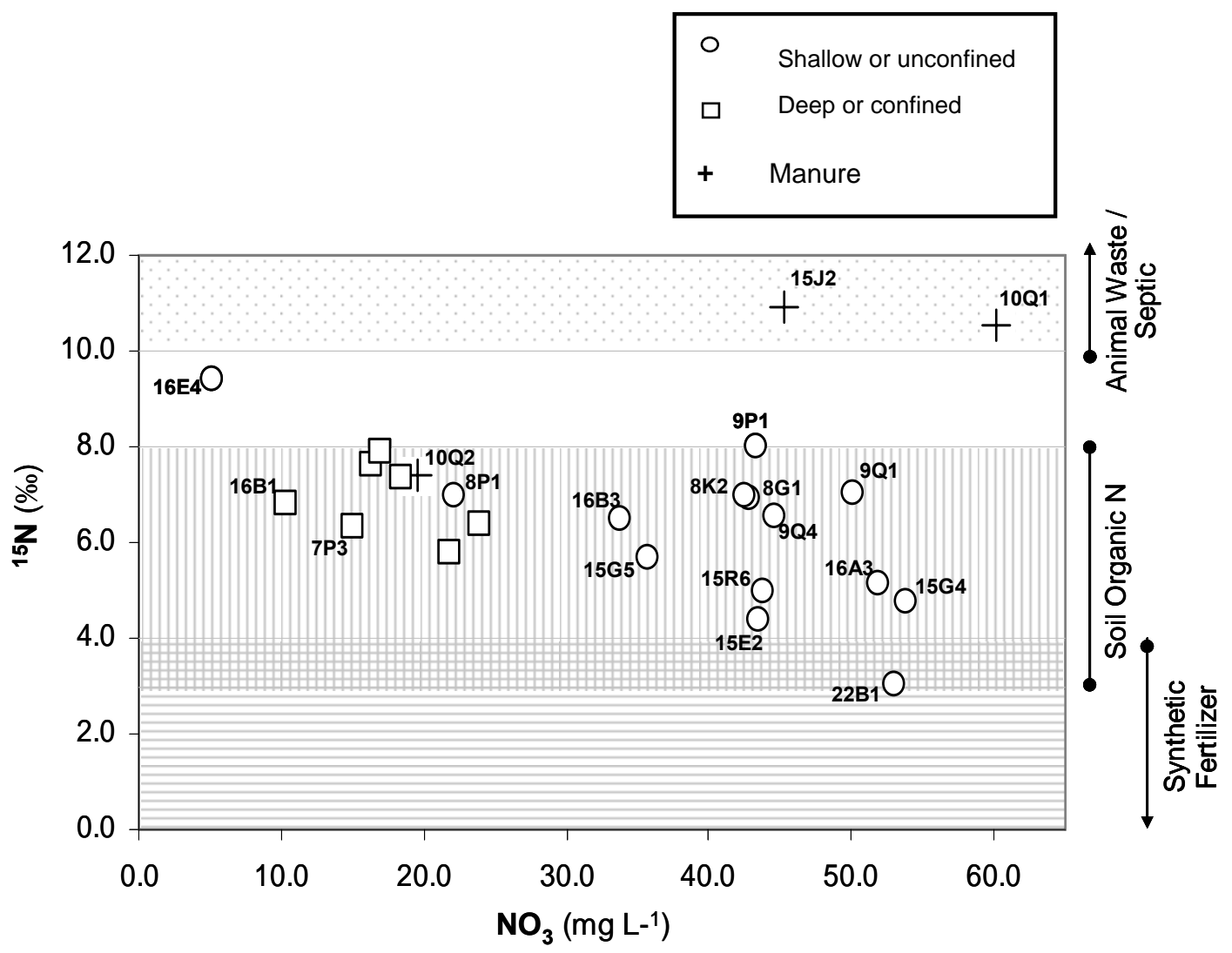

Figure 9a. Nitrate concentrations and $\delta^{15} \mathrm{~N}$ values in groundwater. Expected $\delta^{15} \mathrm{~N}$ ranges for various sources identified. 


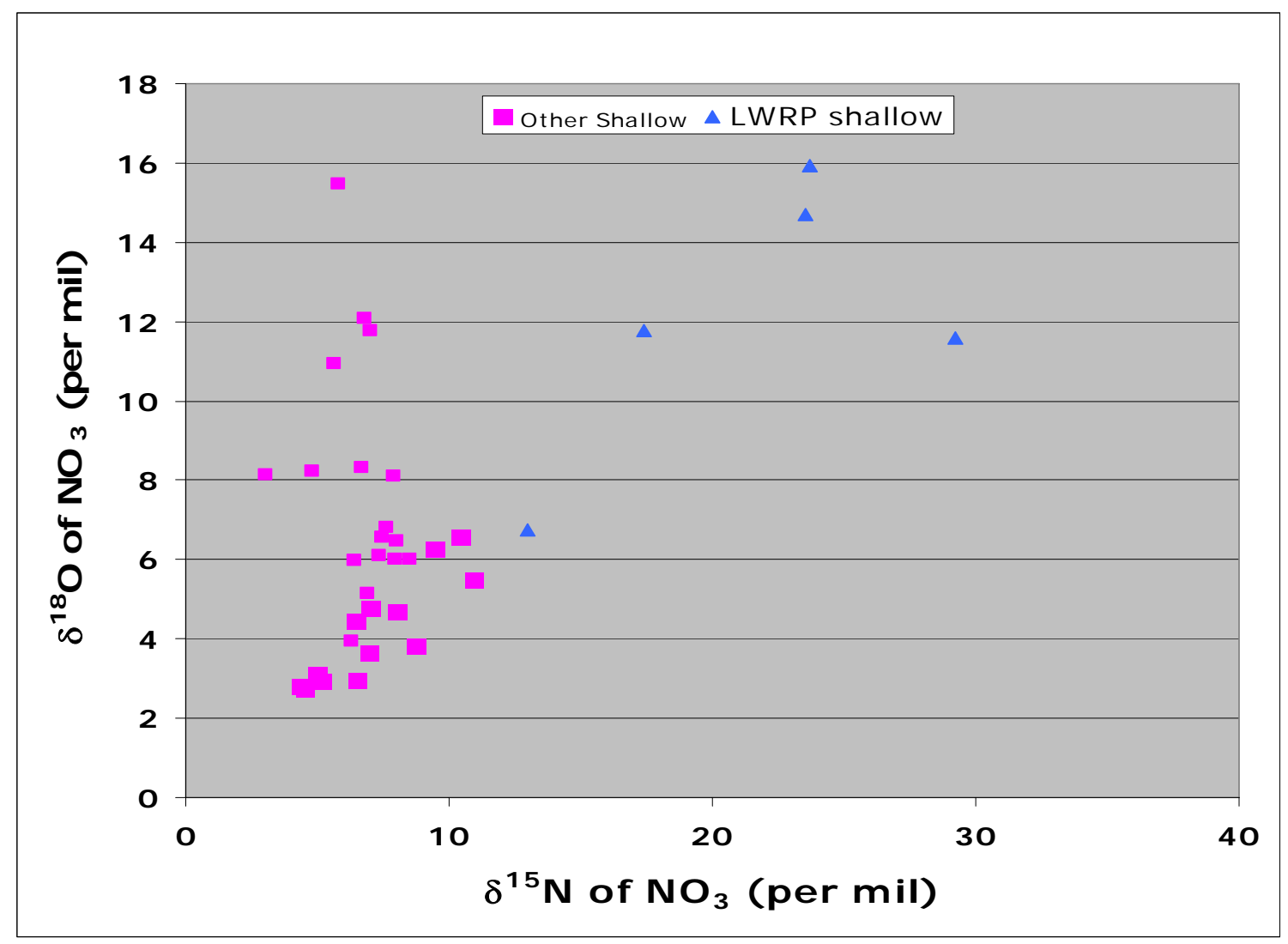

Figure 9b. Shallow wells whose recharge source is treated wastewater from LWRP have isotopic signatures of nitrate that are distinct from other wells and indicate isotopic fractionation by denitrification.

Although this LWRP region was identified as a high nitrate source area in the past (Sylvester, 1983), most of the wells currently have nitrate concentrations well below the MCL (Table 1). The one well within the area of wastewater application for which long term historical data are available, well 2R1, shows concentrations as high as $75 \mathrm{mg} \mathrm{L}^{-1}$ in the late 1970s. After modernization of treatment facilities in 1981, nitrate levels began to drop, reaching concentrations around $10 \mathrm{mg} \mathrm{L}^{-1}$ in the space of just five years. This demonstrates that the new wastewater treatment methods have been successful at reducing nitrogen loading to the aquifer from reclaimed water irrigation.

\section{Manure}

The southeastern region has been identified as the starting point of the high concentration plume. Although the potential nitrate exposures are the same for all of the wells in this area, the ionic composition of wells $15 \mathrm{~J} 2$ and $10 \mathrm{Q} 1$ stands out from the rest (oval area Figure 8). The more northerly flowpath on which these wells lie is likely impacted by a different primary nitrate source than the rest of the valley (Figure 8 and Figure 9a). Measured nitrate- $\delta^{15} \mathrm{~N}$ values greater than $10 \%$ identify animal waste as the nitrate source in these wells, but these isotope data do not distinguish between manure and septic inputs. Examining observed historical trends provides further insight. Time 
series reconstructions of past nitrate concentrations at these wells show that both have had a trend of significantly decreasing nitrate concentrations for at least twenty years (Figure 10a). Current nitrate concentrations at both wells are less than a third of peak values and are nearly at the MCL. Although some modern nitrate sources may remain, it seems that a major source has been discontinued or significantly diminished. Because septic and fertilizer input in this area have remained steady or have increased over the last few decades, historical livestock waste (most active inputs approximately 1950 to 1975) is implicated as a major contributor to nitrate contamination along this flowpath.

Tritium-helium mean residence times of 4 and 9 years in wells 10Q1 and 15J2 demonstrate rapid recharge in this manure-impacted area. As discussed above, however, the contamination in this water comes from sources that were present at the land surface decades ago. This describes a situation in which historical contamination stored in the vadose zone is being flushed into the groundwater over time. This rapid flow and historically-sourced nitrate contamination affects only the shallow part of the aquifer; well 10Q2, $80 \mathrm{~m}$ deeper than well 10Q1, has a nitrate concentration of $19.6 \mathrm{mg} \mathrm{L}^{-1}$, compared to $60.2 \mathrm{mg} \mathrm{L}^{-1}$ in the shallow well. No tritium was detected in well 10Q2, indicating that water at this depth is at least 50 years old. The sum of the evidence therefore suggests limited vertical flow and little interaction between the upper and lower aquifers in this area of thin alluvial fill.

a)

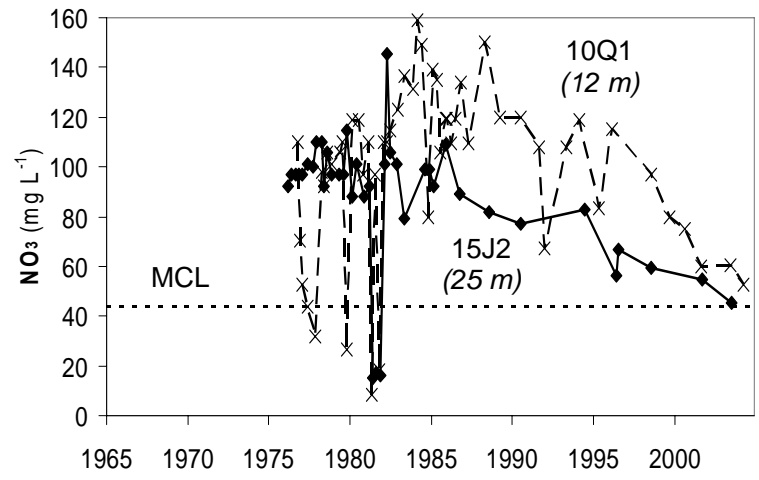

b)

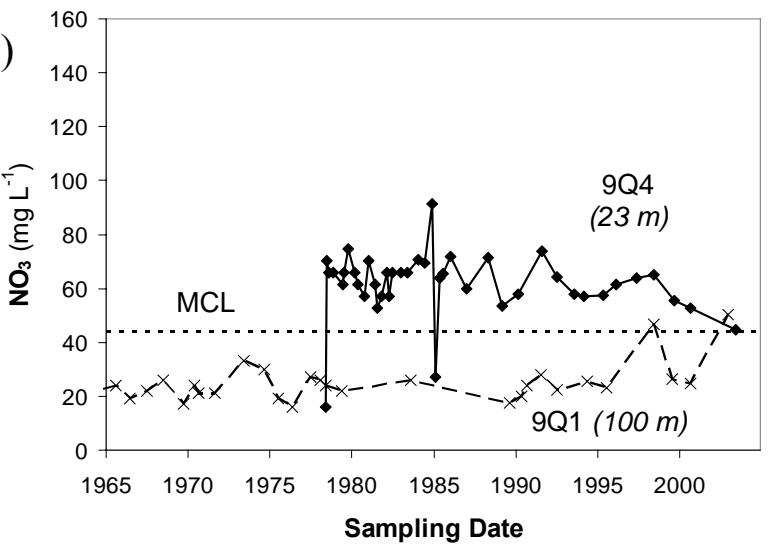

Figure 10. Nitrate concentration time series data. Drinking water maximum contaminant level (MCL) shown for reference. Well depths indicated. (a) Manure flowpath. (b) Alluvial channel flowpath. 


\section{Fertilizer and Soil Organic Nitrogen}

To supplement nitrate-source information provided by nitrate concentration and isotope data, historical ion data combined with residence time measurements yield critical information regarding the impacts of natural background processes versus the impacts of past or present anthropogenic processes. It is constructive to consider data grouped by the depth of the wells and the hydrogeological layers they tap rather than by geographic location alone. The main trend identified by the anion data, which covers a wide area where diffuse recharge and discharge (pumping) complicate the flow system, is considered as two groups. In one group, wells either pump from aquifers confined beneath several aquicludes or else are predominantly screened at depths greater than 80 m. Three deep wells with tritium concentrations of less than $1 \mathrm{pCi} / \mathrm{L}$ (wells 7P3, 7R3, and 10Q2; Table 1) provide an archive of groundwater that recharged before major inputs of non-natural nitrate. At these wells, groundwater is not impacted significantly by the shallow zone contamination, suggesting that the nitrate detected here represents a natural background. Yet nitrate concentrations in these wells are between $15 \mathrm{mg} \mathrm{L}^{-1}$ and $20 \mathrm{mg}$ $\mathrm{L}^{-1}$, which is higher than generally expected for nitrate from non-anthropogenic sources (Nolan, 2002). As discussed above, this result can be explained by nitrogen-fixing vegetation in Livermore's semi-arid climate. Nitrate- $\delta{ }^{15} \mathrm{~N}$ values between $6.3 \%$ and $7.6 \%$ support the hypothesis of soil organic nitrogen as a natural nitrate source. Other deep wells produce groundwater that is a mixture of post-modern tritiated water and water recharged more than 50 years ago. The higher nitrate values observed at these wells reflect young, high nitrate water mixed with 'old' groundwater, which likely dilutes the nitrate concentration to some extent. Deeper penetration of younger water in these wells is the result of the influence of pumping patterns and of location with respect to the arroyo and to overlying alluvial fill. 


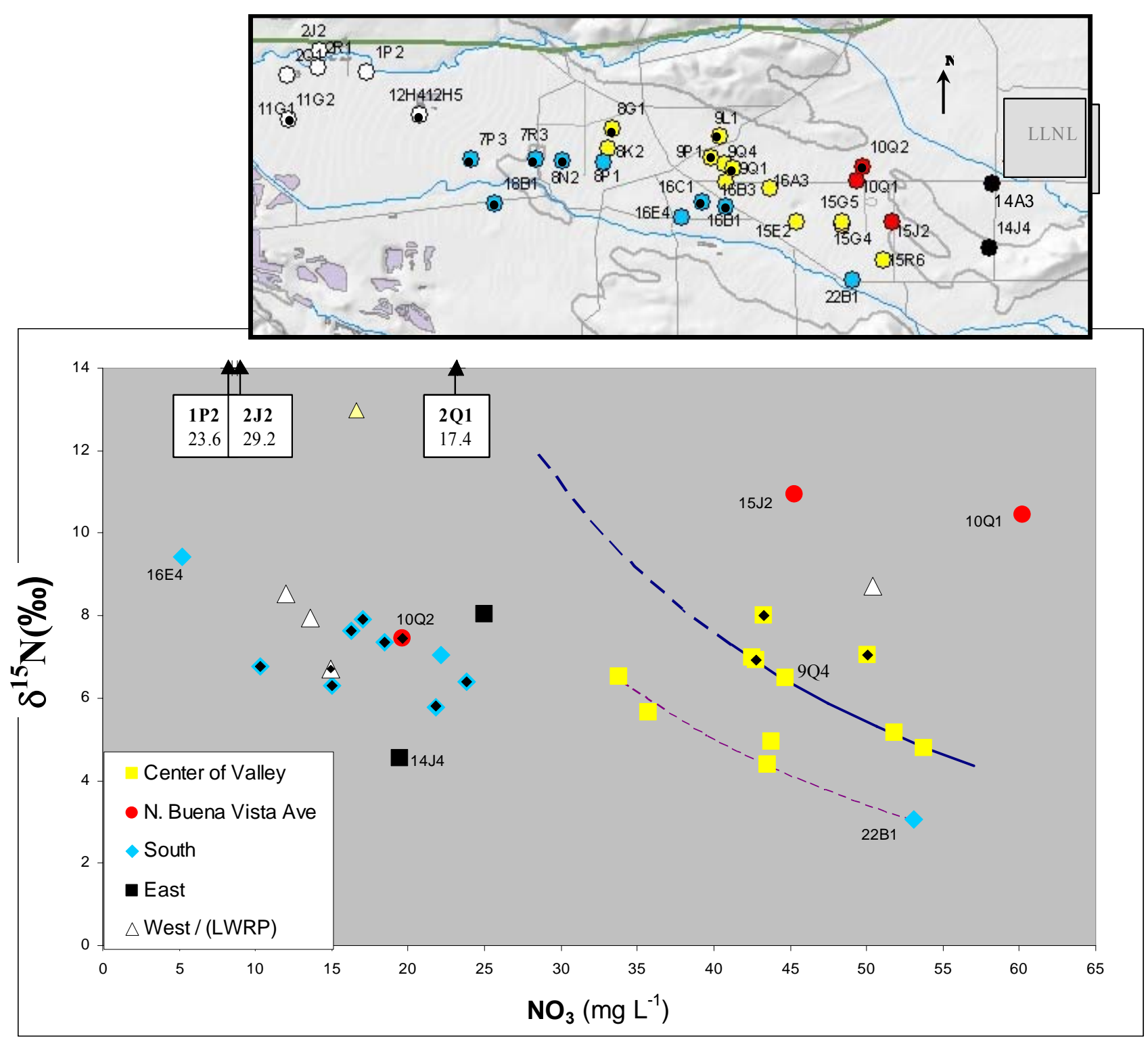

Figure 11. Nitrate concentrations plotted versus nitrogen isotope ratio reveal the distinct groupings based on nitrate source. Possible mixing trends along the alluvial channel flowpath (Center of Valley) are also shown. Symbols with dots indicate wells greater than $35 \mathrm{~m}$ deep.

The rest of the samples fitting the main anion trend are found in wells that draw primarily from the top alluvial layer. This group includes all wells along the flowpath following the central alluvial channel plus the shallow wells between this channel and Arroyo Mocho (Figure 6). The alluvial channel flowpath follows roughly the same course as the nitrate plume originating in the southeast. In contrast to the manure flowpath that also originates in that area, however, nitrate concentrations in wells along the alluvial channel have been steady or rising throughout the last few decades. Well 9Q4 is representative of the alluvial channel wells in the shallow zone of the aquifer. Nitrate levels there averaged around $65 \mathrm{mg} \mathrm{L}^{-1}$ for two decades until a moderate decline was observed over the last five years (Figure 10b). In the deeper alluvial channel wells, 
nitrate levels have been increasing slowly, so that even the deepest well (9Q1) has recently surpassed the MCL (Figure 10b). This supports the depiction of a separate nitrate source along this flowpath and suggests a source with continuing input rather than a historical source. Furthermore, groundwater pumping for municipal supply from wells screened over long intervals may drawn nitrate contaminated water to greater depths in the discharge area.

Well 22B1 is particularly useful in providing the chemical and isotopic signature of the contaminated alluvial channel end-member, since it is situated at the head of the source area, has a high nitrate concentration, and produces very recently recharged groundwater. This well is at the southeastern perimeter of the nitrate contamination plume and adjacent to Arroyo Mocho (Figure 11). Multi-tracer data reveal unusual conditions in this area that provide important insight into the origin of the contamination. Well 16E4 is another shallow well adjacent to the arroyo but several kilometers to the west of well 22B1. Light stable isotopes of water at both wells indicate that they draw the majority of their water from recharge of SBA water along the arroyo (Figure 6). Tritium-helium residence times of less than one year at both wells also indicate that rapid recharge from the arroyo is a significant source of shallow groundwater proximal to the arroyo (Figure 7). Despite this evidence that these two wells have the same source of water, their observed nitrate concentrations are very different. Well 16E4 generally has less than $10 \mathrm{mg} \mathrm{L}^{-1} \mathrm{NO}_{3}$ while well 22B1 historically fluctuates between $30 \mathrm{mg} \mathrm{L}^{-1}$ and $80 \mathrm{mg} \mathrm{L}^{-1} \mathrm{NO}_{3}$ (unpublished data, Zone 7, 2003). SBA water contributes little nitrate, with an average concentration over the last 10 years of $2.5 \mathrm{mg} \mathrm{L}^{-1}$ (State of California, 2004). To reach the high nitrate levels seen at 22B1, then, recharge through the arroyo must mobilize a local source of nitrate in its short travel time to the well. This represents a substantial amount of nitrogen moving through the system, and must either be supplied by a large reserve stored in the soil or vadose zone or by a source that is continually being replenished. Either a soil or fertilizer source, therefore, is implicated as the source of nitrate in this location.

All nitrate concentrations measured in the alluvial region were greater than $33 \mathrm{mg}$ $\mathrm{L}^{-1}$ and $\delta^{15} \mathrm{~N}$ values were less than $8 \%$ (Figure 11). Well 22B1 and well 15G4 have the highest nitrate concentrations, at 53.1 and $53.8 \mathrm{mg} \mathrm{L}^{-1}$. The nitrate- $\delta^{15} \mathrm{~N}$ values here are in the low range expected for synthetic fertilizer (3.1\%o and $4.8 \%$, respectively). This overlaps the low end of the range for nitrate from reduced soil nitrogen, another potential source given these wells' location downgradient of vineyards and grassland. Although nitrogen isotopes alone cannot distinguish between these two sources, it is unlikely that concentrations as high as $80 \mathrm{mg} \mathrm{L}^{-1}$, which have been measured at well 22B1, result from soil nitrogen inputs alone. As groundwater flows from the southeast to the northwest along the alluvial channel flowpath, the trend, originating at well 22B1, is towards decreasing nitrate concentrations and increasing $\delta^{15} \mathrm{~N}$ values (Figure 11). In the absence of denitrification, remineralizing nitrate in the soil and mixing with uncontaminated water would result in such a trend toward decreased nitrate concentrations and increasing nitrate- $\delta{ }^{15} \mathrm{~N}$ values into the range expected for soil nitrogen (Choi, 2003).

Nitrate- $\delta{ }^{18} \mathrm{O}$ data provide further evidence for a fertilizer source of nitrate in this area. Wells 22B1, 15G4, and $15 \mathrm{G} 5$ have nitrate- $\delta^{18} \mathrm{O}$ values between $8.1 \%$ and $10.9 \%$ (Table 1), relatively high compared to the values found at the other shallow wells with low $\delta^{15} \mathrm{~N}$, which range from $2.8 \%$ o to $4.8 \%$ nitrate- $\delta^{18} \mathrm{O}$. High nitrate- $\delta^{18} \mathrm{O}$ is consistent 
with a synthetic fertilizer nitrate source. Nitrate from synthetic fertilizer generally has a nitrate- $\delta^{18} \mathrm{O}$ value around $23 \%$ (Kendall and Aravena, 2000), while ammonium nitrate fertilizer, with approximately $50 \%$ of its oxygen from fertilizer nitrate and $50 \%$ from nitrified fertilizer ammonium, would be expected to have a nitrate- $\delta^{18} \mathrm{O}$ value of approximately $13 \%$ in this environment (Aravena et al., 1993).

According to our interpretation of the available data, which include nitrate distributions and isotopes, water compositions, stable isotopes of water, and tritiumhelium residence times, several flowpaths originate in the southeastern region of the valley, one primarily impacted by historical manure sources and the other with a significant modern synthetic fertilizer component. Inverse geochemical modeling validates that this is a realistic explanation by postulating mixing ratios and sets of mass transfer reactions to explain differences in chemical composition between water samples along these flowpaths. Selected inverse modeling results for both flowpaths (i.e., mass transfer reactions that plausibly explain differences in major ion water chemistry between nitrate-impacted and background water compositions) are compared in Figure 12. These modeling results suggest that the loading of an organic carbon component (and its subsequent oxidation) can be associated with the manure flowpath but is not required for the alluvial channel flowpath. The inverse modeling also suggests a significant role for dilution along the manure flowpath - most probably from local rainfall recharge. As stated previously, however, variability in the oxygen isotopic composition of the local precipitation precludes direct validation of this model result. Inverse geochemical models are typically non-unique, and the set of results shown in Figure 12 is only one example of the multiple variations that are possible to account for observed behavior. Other postulated reactions along both flowpaths include replacement of Mg-rich carbonate phases with generally more Ca-rich equivalents as well as addition of salts and/or ion exchange reactions. Nevertheless, a valid inverse model that is consistent with the water composition evolution hypothesis formulated upon separate lines of evidence, described above, is of significant utility in validating the internal consistency of this hypothesis. 


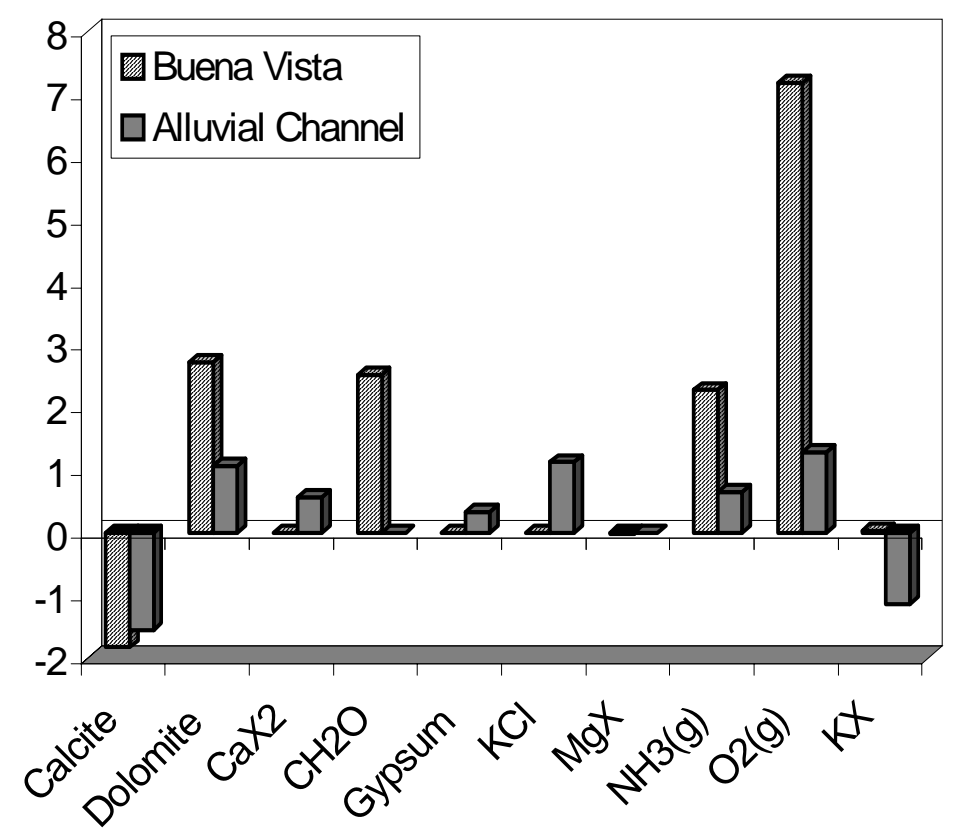

Figure 12. Geochemical modeling results. One set of inverse modeling results indicating mass transfer reactions that can account for differences in nitrate-impacted and background water compositions along the manure and alluvial channel groundwater flowpaths. In addition to the mass transfer reactions plotted, the manure flowpath includes a $43 \%$ dilution of the nitrate-impacted water with rainwater. This scenario requires input of organic carbon along the manure flowpath, but not along the alluvial channel flowpath.

\section{Conclusions and Recommendations:}

In this study, the separation of nitrate sources introduced decades ago is made possible by a multiple-analysis approach using current and historical data. Stable isotopes provide information about water sources, while tritium-helium age dating defines groundwater residence times and transport behavior. In addition, dissolved gas and nitrate isotope evidence indicate that nitrate moves conservatively in the groundwater, which simplifies source attribution. Nitrate isotope measurements are then combined with information about land use history to identify contaminant sources. This integrated approach reveals a much larger role for fertilizer and natural soil nitrogen than suggested by prior assessments, which used source mass and plume delineation methods to attribute most of the contamination to septic tanks and livestock. In addition to identifying contaminant sources, these methods offer a deeper understanding of how the severity and extent of contamination is affected by hydrogeology and groundwater management practices. In this case, the nitrate problem is amplified by artificial recharge in the source area, a region where the aquifer is vulnerable because it is unconfined and experiences high vertical recharge. This approach can be widely applied to other regions with historical nitrate inputs and can provide valuable information to water managers in evaluating future mitigation strategies. 


\section{Acknowledgments}

We thank Chris Eastoe of the University of Arizona's Department of Geosciences, and the University of Waterloo's Environmental Isotope Laboratory for laboratory analyses. We are grateful to Zone 7 personnel, in particular Colleen Winey, Matthew Katen, Gerry Gates, and David Lunn, for assisting with collection of field samples and for sharing data and information about local hydrogeology. 


\section{REFERENCES}

Aravena, R.; Evans, M. L.; Cherry, J. A. Stable isotopes of oxygen and nitrogen in source identification of nitrate from septic systems. Ground Water 1993, 31(2), 180-186.

Bayer, R.; Schlosser, P.; Bönisch, G.; Rupp, H.; Zaucker, F.; Zimmek, G. Performance and blank components of a mass spectrometric system for routine measurement of helium isotopes and tritium by the ${ }^{3} \mathrm{He}$ ingrowth method., 5, pp., Sitzungsberichte der Heidelberger Akademie der Wissenschaften Mathematisch-naturwissenschaftliche Klasse, Berlin, 1989.

Beyerle, U.; Aeschbach-Hertig, W.; Imboden, D. M.; Baur, H.; Graf, T.; Kipfer R. Amass spectrometric system for the analysis of noble gases and tritium from water samples. Env. Sci. Technol. 2000 34(10), 2042-2050.

Bohlke, J. K.; Denver, J. M. Combined use of groundwater dating, chemical, and isotopic analyses to resolve the history and fate of nitrate contamination in two agricultural watersheds, Atlantic coastal plain, Maryland. Water Resour. Res. 1995, 31, 2319-2339.

Bohlke, J.K. Groundwater recharge and agricultural contamination. Hydrogeol. J. 2002, 10, 153-179.

Brenner, D. L.; Amundsen, R.; Baisden, T.; Kendall, C.; Harden, J. Soil N and 15N variation with time in a California annual grassland ecosystem. Geochim. Cosmochim. Acta 2001, 65, 4171-4186.

Burow, K. R.; Shelton, J. L.; Dubrovsky, N. M. Occurrence of nitrate and pesticides in ground water beneath three agricultural land-use settings in the eastern San Joaquin Valley, California, 1993-1995: U.S. Geological Survey Water Resource Investigation Report 97-4284; U.S. Geological Survey: Sacramento, 1998.

California Department of Health Services. Drinking Water: Overview of Monitoring Results 1994-2003, and an Indication of Dominant Contaminants (4/20/04 Update). http://www.dhs.ca.gov/ps/ddwem/chemicals/monitoring/results94$\underline{03 . h t m}$

Choi, W.-J.; Lee, S.-M.; Ro, H.-M. Evaluation of contamination sources of groundwater nitrate using nitrogen isotope data: A review. Geosci. J. 2003, $7(1), 81-87$.

Eaton, G. F.; Hudson, G. B.; Moran, J. E. Tritium-helium-3 age-dating of groundwater in the Livermore Valley of California. Lawrence Livermore National Laboratory. 2003.

Edmunds, W. W.; Gaye, C. B. Naturally high nitrate concentrations in groundwaters from the Sahel. J. Environ. Qual. 1997, 26, 1231-1239. 
Epstein, S.; Mayeda, T. Variation of O-18 content of waters from natural sources. Geochim. Cosmochim. Acta 1953, 4, 213-227.

Flatt, H.; Heemskerk, A. R. ${ }^{15} N /{ }^{18} \mathrm{O}$ in Dissolved Nitrate. Environmental Isotope Laboratory, Department of Earth Sciences, University of Waterloo, 1997.

Global Network of Isotopes in Precipitation (GNIP) and Isotope Hydrology Information System (ISOHIS). http://ishois.iaea.org (Santa Maria, CA; precipitation; 1962-1976)

Griggs, E. M.; Kump, L. R.; Bohlke, J. K. The fate of wastewater-derived nitrate in the subsurface of the Florida Keys: Key Colony Beach, Florida. Estuar. Coast. Shelf Sci. 2003, 58, 517-539.

Hajrasuliha, S.; Rolston, D. E.; Louie, D. T. Fate of N-15 fertilizer applied to trickleirrigated grapevines. Am. J. Enol. Viticult. 1998, 49, 191-198.

Hudson, G. B.; Moran, J. E.; Eaton, G. F. Interpretation of Tritium-3Helium Groundwater Ages and Associated Dissolved Noble Gas Results from Public Water Supply Wells in the Los Angeles Physiographic Basin Interpretation of Tritium-3Helium Groundwater Noble Gas Results from Public Water Supply Wells in the Los Angeles Physiographic Basin: Report to the California State Water Resources Control Board. Lawrence Livermore National Laboratory. 2002. http://www.1lnl.gov/tid/lof/documents/pdf/245359.pdf

Jordan, M. J.; Nadelhoffer, K. J.; Fry, B. Nitrogen cyclic in forest and grass ecosystems irrigated with $15 \mathrm{~N}$ enriched wastewater. Ecol. Appl. 1997, 7, 864-881.

Kana, T. M.; Darkangelo, C.; Hunt, M. D.; Oldham, J. B.; Bennett, G. E.; Cornwell, J. C. Membrane inlet mass spectrometer for rapid high-precision determination of nitrogen, oxygen, and argon in environmental water samples. Anal. Chem. 1994, $66,4166-4170$.

Karr, J. D.; Showers, W. J.; Gilliam, J. W.; Andres, A. S. Tracing nitrate transport and environmental impact from intensive swine farming using delta $\mathrm{N}-15$. J. Environ. Qual. 2001, 30, 1163-1175.

Kendall, C.; Grim, E. Combustion tube method for measurement of nitrogen isotope ratios using calcium oxide for total removal of carbon dioxide and water. Anal. Chem. 1990, 62, 526-529.

Kendall, C.; Aravena, R. Nitrate Isotopes in Groundwater Systems. In Environmental Tracers in Subsurface Hydrology; Cook, P. G., Herczeg, A. L., Eds.; Kluwer Academic Publishers: Norwell, Massachusetts, 2000; pp 261-297.

Lucas, L. L.; Unterwerger, M. P. Comprehensive review and critical evaluation of the half-life of tritium. Journal of Research of the National Institute of Standards and Technology 2000, 105, 541-549. 
Moran, J. E.; Hudson, G. B.; Eaton, G. F.; Leif, R. A contamination vulnerability assessment for the Livermore-Amador and Niles Cone groundwater basins, California State Water Resources Control Board, 2002.

Morse, J.W.; Mackenzie, F. T. Geochemistry of Sedimentary Carbonates, Developments in Sedimentology 48, Elsevier, Amsterdam, 1990; pp. 295-309.

National Research Council, Committee on Long-Range Soil and Water Conservation, Board of Agriculture. Soil and water quality: An agenda for agriculture; National Academy Press: Washington, D.C., 1993.

Nolan, B. T.; Hitt, K. J.; Ruddy, B. C. Probability of nitrate contamination of recently recharged groundwaters in the conterminous United States. Environ. Sci. Technol. 2002, 36, 2138-2145.

Parkhurst D. L.; Appelo C. A. J. User's Guide to PHREEQC (Version 2) - A Computer Program for Speciation, Batch Reaction One-Dimensional Transport, and Inverse Geochemical Calculations: U.S. Geological Survey Water Resource Investigation Report 99-4259; U.S. Geological Survey: Denver, 2002.

Raines, Melton, and Carella, Inc. Groundwater Nitrate Sources in the Buena Vista Area. Report to Alameda County Flood Control and Water Conservation District, Zone 7, 2002.

Rees, G. R. Tracing ground water movement in the eastern Livermore Valley, Alameda County, California, using stable isotopes, major ion chemistry, and a line source model. Lawrence Livermore National Laboratory. 1994.

Rozanski, K. L.; Araguas-Araguas, L.; Gonfiantini, R. Isotopic patterns in modern global precipitation. In Climate Change in Continental Isotopic Records, Geophysical Monograph 78; Swart, P. K.; McKenzie, J.; Lohmann. K. C.; Savin, S. Eds.; American Geophysical Union: Washington, D.C., 1993; pp1-36.

Schlosser, P.; Stute, M.; Sontag, C.; Munich, K. O. Tritiogenic ${ }^{3} \mathrm{He}$ in shallow groundwater. Earth Planet. Sci. Lett. 1989, 94, 245-256.

Segura, S. Main Basin Groundwater Hydrologic Inventory, 1974 - 2003. Memorandum to Water Resources Manager, Alameda County Flood Control and Water Conservation District, Zone 7, 2004. http://www.zone7water.com/reports.html

Silva, S. R.; Kendall, C.; Wilkison, D. H.; Ziegler, A. C.; Chang, C. C. Y.; Avanzino, R. J. A new method for collection of nitrate from fresh water and the analysis of nitrogen and oxygen isotope ratios. J. Hydrol. 2000, 228, 22-36.

Solomon, D. K.; Cook, P. G. 3H and 3He. In Environmental Tracers in Subsurface Hydrology; Cook, P. G., Herczeg, A. L., Eds.; Kluwer Academic Publishers: Norwell, Massachusetts, 2000; pp 397-424. 
Sorenson, S. K.; Cascos, P.V.; Glass, R. L. Water-quality conditions and an evaluation of ground-and surface-water sampling programs in the Livermore-Amador Valley, California: U.S. Geological Survey Water Resources Investigation Report 84-4352; U.S. Geological Survey: Sacramento, 1984.

State of California, Department of Water Resources. Bulletin No. 118-2: Livermore and Sunol Valleys, Evaluation of ground water resources; Appendix A, Geology. 1967.

State of California, Department of Water Resources, Water Data Library, Water Quality Data. http://wdl.water.ca.gov/wq/gst/water_quality_report1_gst.asp (Station: Banks, County: Alameda, Dates: 9/93 to 9/03.) Accessed June, 2004.

Steinbergs, C.; Wong, V. Preliminary Assessment of Nitrate-Nitrogen Loading Agents and Removal Mechanisms Impacting Local Ground Waters Within the Livermore - Amador Valley of California, Zone 7, Alameda County Flood Control and Water Conservation District, 1980.

Sylvester, M.A. Land application of wastewater and its effect on ground-water quality in the Livermore-Amador Valley, Alameda County, California: U.S. Geological Survey Water Resources Investigation Report 82-4100; U.S. Geological Survey: Sacramento, 1983.

Vogel, J. C.; Talma, A. S.; Heaton, T. H. E. Gaseous nitrogen as evidence for denitrification in groundwater. J. Hydrol. 1981 50, 191-200.

Williams, A. E.; Lund, L. J.; Johnson, J. A.; Kabala, Z. J. Natural and anthropogenic nitrate contamination of groundwater in a rural community, California. Environ. Sci. Technol. 1998, 32, 32-39. 


\begin{tabular}{|c|c|c|c|c|c|c|c|c|c|c|}
\hline \multirow{3}{*}{$\begin{array}{c}\text { Well } \\
\text { ID }\end{array}$} & \multirow{3}{*}{$\begin{array}{c}\text { Well } \\
\text { Type }^{\text {b }}\end{array}$} & \multicolumn{2}{|c|}{ Well Screen } & \multirow{3}{*}{$\begin{array}{l}\mathrm{NO}_{3}{ }^{\mathrm{d}} \\
\mathrm{mg} / \mathrm{L}\end{array}$} & \multirow{3}{*}{$\begin{array}{l}\delta^{2} \mathrm{H}^{\mathrm{d}} \\
\left(\mathrm{H}_{2} \mathrm{O}\right) \\
-----p e r\end{array}$} & \multirow{3}{*}{$\begin{array}{l}\delta^{18} \mathrm{O}^{\mathrm{d}} \\
\left(\mathrm{H}_{2} \mathrm{O}\right) \\
\text { mil -- }\end{array}$} & \multirow{3}{*}{$\begin{array}{l}{ }^{3} \mathrm{H}^{\mathrm{d}} \\
\text { age } \\
y r \\
\end{array}$} & \multirow{3}{*}{$\begin{array}{c}\text { Recharge } \\
\text { Temp } \\
{ }^{\circ} C \\
\end{array}$} & \multirow{3}{*}{$\begin{array}{l}\delta^{15} \mathrm{~N}^{\mathrm{d}} \\
\left(\mathrm{NO}_{3}\right) \\
----p e r\end{array}$} & \multirow{3}{*}{$\begin{array}{r}\delta^{18} \mathrm{O}^{\mathrm{d}} \\
\left(\mathrm{NO}_{3}\right) \\
\text { mil ----- }\end{array}$} \\
\hline & & Top & Bottom & & & & & & & \\
\hline & & $m$ below & surface & & & & & & & \\
\hline $1 \mathrm{P} 2$ & MW & 12.2 & 13.7 & 8.4 & -53 & -7.0 & 8 & 14.4 & 23.6 & 15.9 \\
\hline $1 \mathrm{P} 2$ & MW & \multicolumn{2}{|c|}{ same as above } & 8.2 & $-52^{\mathrm{e}}$ & -6.9 & - & - & 23.6 & 14.7 \\
\hline $2 \mathrm{~J} 2$ & MW & 9.5 & 12.5 & 8.8 & -51 & -7.1 & - & - & 29.2 & 11.6 \\
\hline 2Q1 & MW & 10.7 & 13.7 & 23.3 & -52 & -7.3 & - & - & 17.4 & 11.8 \\
\hline 2R1 & MW & 6.4 & 7.9 & 16.6 & $-53^{f}$ & -7.3 & - & - & 13.0 & 6.7 \\
\hline $7 \mathrm{P} 3$ & PS & 131.1 & $149.3^{c}$ & 15.0 & -49 & -6.9 & $>50$ & 11.8 & 6.3 & 4.0 \\
\hline 7R3 & PS & 125.0 & 161.0 & 16.3 & -53 & -7.4 & $>50$ & 15.1 & 7.6 & 6.8 \\
\hline $8 \mathrm{G} 1$ & PS & 36.6 & 138.7 & 42.8 & -55 & -7.8 & 21 & 15.7 & 6.9 & 5.2 \\
\hline $8 \mathrm{~K} 2$ & MW & 19.5 & 21.0 & 42.5 & -56 & -7.9 & 10 & 19.8 & 7.0 & 3.6 \\
\hline $8 \mathrm{~N} 2$ & PS & 42.7 & 157.0 & 17.0 & -58 & -8.1 & 14 & 15.8 & 7.9 & 8.1 \\
\hline $8 \mathrm{P} 1$ & PS & 37.2 & 80.2 & 22.1 & -61 & -8.6 & 9 & 15.5 & 7.0 & 4.8 \\
\hline 9P1 & PS & 58.5 & 150.0 & 43.3 & -52 & -7.4 & 21 & 15.8 & 8.0 & 6.5 \\
\hline $9 \mathrm{Q} 1^{\mathrm{a}}$ & PS & 85.4 & $100.6^{\mathrm{c}}$ & 50.1 & -54 & -7.5 & 16 & 15.5 & 7.8 & 11.8 \\
\hline 9Q4 & MW & 21.3 & 22.9 & 44.7 & -57 & -7.8 & 10 & 17.2 & 6.5 & 4.4 \\
\hline 10Q1 & MW & 10.4 & 11.9 & 60.2 & -56 & -7.5 & 9 & - & 10.5 & 6.6 \\
\hline 10Q2 & MW & 90.9 & 99.1 & 19.6 & -50 & -7.0 & $>50$ & - & 7.4 & 6.6 \\
\hline $11 \mathrm{G} 1$ & MW & 30.5 & 33.5 & 50.4 & $-53^{\mathrm{f}}$ & -6.7 & - & - & 8.7 & 3.8 \\
\hline $11 \mathrm{G} 2$ & MW & 70.1 & 103.7 & 12.0 & $-66^{\mathrm{f}}$ & -8.8 & - & - & 8.5 & 6.0 \\
\hline $12 \mathrm{H} 4$ & MW & 56.4 & 79.3 & 13.6 & -62 & -8.6 & 7 & 13.1 & 7.9 & 6.0 \\
\hline 12H5 & MW & 109.8 & 118.9 & 15.0 & -59 & -8.1 & 12 & - & 6.7 & 8.3 \\
\hline $14 \mathrm{~A} 3$ & MW & 30.5 & 32.0 & 25.0 & -55 & -7.6 & 5 & 16.9 & 8.1 & 4.7 \\
\hline $14 \mathrm{~J} 4$ & PV & 30.5 & 71.6 & 19.5 & -50 & -6.9 & $<1$ & 18.5 & 4.5 & 2.8 \\
\hline $15 \mathrm{E} 2$ & PV & 31.7 & 57.6 & 43.5 & -57 & -7.7 & 16 & 19.7 & 4.4 & 2.8 \\
\hline $15 \mathrm{G}^{\mathrm{a}}$ & PV & \multicolumn{2}{|c|}{ unk.; $<33.5$} & 53.8 & -60 & -8.0 & - & - & 4.8 & 8.2 \\
\hline $15 \mathrm{G}^{\mathrm{a}}$ & PV & 12.2 & 30.5 & 35.7 & -54 & -7.4 & - & - & 5.7 & 10.9 \\
\hline $15 \mathrm{~J} 2$ & PV & 33.8 & $40.8^{c}$ & 45.3 & -57 & -7.6 & 4 & 17.6 & 10.9 & 5.5 \\
\hline 15R6 & MW & \multicolumn{2}{|c|}{ unk.; $<17.7$} & 43.8 & -58 & -7.6 & - & - & 5.0 & 3.1 \\
\hline $16 \mathrm{~A} 3$ & MW & 44.2 & $73.2^{\mathrm{c}}$ & 51.8 & -57 & -7.8 & 16 & 21.6 & 5.2 & 2.9 \\
\hline $16 \mathrm{~B} 1^{\mathrm{a}}$ & PS & 42.7 & 118.9 & 10.3 & -55 & -7.8 & 18 & - & 6.8 & 12.1 \\
\hline $16 \mathrm{~B} 1$ & PS & \multicolumn{2}{|c|}{ same as above } & 21.8 & -58 & -8.2 & - & 13.0 & 5.8 & 15.5 \\
\hline $16 \mathrm{~B} 3$ & PV & 0.0 & 24.4 & 33.8 & -57 & -7.9 & - & 20.4 & 6.5 & 3.0 \\
\hline $16 \mathrm{C} 1$ & PS & 87.8 & 159.5 & 18.4 & -55 & -7.6 & - & 13.3 & 7.4 & 6.1 \\
\hline $16 \mathrm{E} 4$ & MW & 10.7 & 12.2 & 5.2 & -66 & -9.1 & $<1$ & 11.8 & 9.4 & 6.3 \\
\hline $18 \mathrm{~B} 1$ & PS & 57.9 & 141.8 & 23.9 & -52 & -7.4 & 11 & 14.5 & 6.3 & 6.0 \\
\hline $22 \mathrm{~B} 1^{\mathrm{a}}$ & MW & 13.7 & 15.2 & 53.1 & -64 & -8.6 & $<1$ & - & 3.1 & 8.1 \\
\hline
\end{tabular}

a Collected in 1/03. All other samples collected between 6/03 and 8/03. Multiple samplings at 1P2, in 6/03 and 8/03, and at $16 \mathrm{~B} 1$, in $1 / 03$ and $7 / 03$.

b $\mathrm{MW}=$ monitoring well; $\mathrm{PS}=$ public supply well; $\mathrm{PV}=$ private well.

c Longest of multiple screens. Also screened at: 7P3 - 91.5 to $97.6 \mathrm{~m} ; 9 \mathrm{Q} 1-38 \mathrm{~m}$ screens from 103.0 to $140.5 ; 15 \mathrm{~J} 2$ -23.2 to $24.7 \mathrm{~m} ; 16 \mathrm{~A} 3-27.7$ to $36.9 \mathrm{~m}$.

d Average Errors: $\mathrm{NO}_{3}( \pm 2.7 \%), \mathrm{Cl}( \pm 4.6 \%), \mathrm{SO}_{4}( \pm 1.7 \%), \delta^{2} \mathrm{H} \mathrm{H} \mathrm{H}_{2} \mathrm{O}( \pm 0.9 \%), \delta^{18} \mathrm{O} \mathrm{H}_{2} \mathrm{O}( \pm 0.1 \%),{ }^{3} \mathrm{H}( \pm 2 \mathrm{yr}), \delta^{15} \mathrm{~N}$ $\mathrm{NO}_{3}( \pm 0.3 \%), \delta^{18} \mathrm{O} \mathrm{NO}_{3}( \pm 0.9 \%), \mathrm{N}_{2}( \pm 2 \%$ standard deviation [s.d.]), $\mathrm{Ar}( \pm 2 \%$ s.d. $)$.

e Data provided by Zone $7 . \quad{ }_{f}$ Measured at LLNL.

Table 1. Well data and chemical and isotopic analyses of samples. 
